NATL INST OF STAND \& TECH

\title{
Flame Spread on Combustible Solar Collector Glazing Materials
}

U.S. DEPARTMENT OF COMMERCE

National Bureau of Standards

Center for Fire Research

Gaithersburg, MD 20899

July 1984

Final Report

Supported in part by:

Department of Energy

Office of Solar Heat Technologies

Active Heating and Cooling Division

100

Washington, DC 20585

.056 



\section{FLAME SPREAD ON COMBUSTIBLE SOLAR COLLECTOR GLAZING MATERIALS}

Emil Braun

Paula J. Allen

U.S. DEPARTMENT OF COMMERCE

National Bureau of Standards

Center for Fire Research

Gaithersburg, MD 20899

July 1984

Final Report

Supported in part by:

Department of Energy

Office of Solar Heat Technologies

Active Heating and Cooling Division

Washington, DC 20585

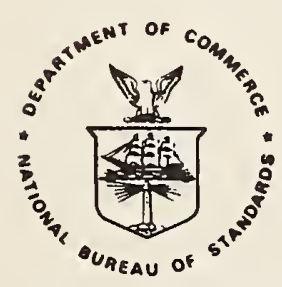

U.S. DEPARTMENT OF COMMERCE, Malcolm Baldrige, Secretary NATIONAL BUREAU OF STANDARDS, Ernest Ambler, Director 
TABLE OF CONTENTS

$\underline{\text { Page }}$

LIST OF TABLES . . . . . . . . . . . . . . . . . . iv

LIST OF FIGURES . . . . . . . . . . . . . . . . . . v

Abstract . . . . . . . . . . . . . . . . . . 1

1. INTRODUCTION . . . . . . . . . . . . . . . . 1

2. BACKGROUND . . . . . . . . . . . . . . . . 3

2.1 Solar Collector Fires and Performance Requirements . . 3

2.2 Flame Spread . . . . . . . . . . . . . . 4

3. TEST MATERIALS .................. . . 5

3.1 Dimensional Properties . . . . . . . . . . . 5

3.2 Fire Properties ............... . 6

3.2.1 Bunsen Burner Test . . . . . . . 6

3.2.2 Ignition Tests .............. 7

3.2.3 Flame Spread Tests ........... 9

3.2.4 Rate of Heat Release ........... 11

4. LARGE SCALE TESTS . . . . . . . . . . . . . . 13

4.1 Experimental Design . . . . . . . . . . . 13

4.2 Instrumentation .. . . . . . . . . . . . 14

4.3 Results .................. . . 15

5. DISCUSSION ................. 18

5.1 Correlation Between ASTM D635 and Other Tests . . . 18

5.2 Evaluation of Bench-Scale to Large-Scale Correlation . 20

6. CONCLUSIONS . . . . . . . . . . . . . . 21

7. ACKNOWLEDGEMENTS . . . . . . . . . . . . 22 


\section{LIST OF TABLES}

$\underline{\text { Page }}$

Table 1. Description of Materials Used in Small-Scale Tests . . 25

Table 2. Summary of ASTM D635 Test Results . . . . . . . 26

Table 3. A Comparison of Minimum Incident Flux, q", ig, . . . . 27
Necessary for Ignition . . . . . . . .

Table 4. Comparison of Time to Flame Attachment (TFA) for

Ease of Ignition Test and Ignition Time for ISO

Apparatus at $34 \mathrm{~kW} / \mathrm{m}^{2}$. . . . . . . . . 28

Table 5. Summary of Test Results Using ASTM E162 Average

Values for Three Samples . . . . . . . . 29

Table 6. Summary of Test Results From the ISO Apparatus . . . 30

Table 7. Summary of Data Obtained From The Cone Calorimeter at $25 \mathrm{~kW} / \mathrm{m}^{2}$ and Spark Induced Ignition . . . . . 31

Table 8. Maximum Values Obtained from Roof

Mounted Instrumentation . . . . . . . . 32

Table 9. Summary of Specimen Ranking ............ 33 
Figure 1. ASTM D635 Apparatus . . . . . . . . . . . 34

Figure 2. Sketch of Ignition Apparatus . . . . . . . . . 35

Figure 3. Schematic of ISO Flame Spread Apparatus . . . . . 36

Figure 4. Time for Piloted Ignition as a Function of External Radiant Flux Using ISO Apparatus . . . . . . 37

Figure 5. Time for Piloted Ignition as a Function of External Radiant Flux Using ISO Apparatus . . . . . . 38

Figure 6. Time for Piloted Ignition as a Function of External Radiant Flux Using ISO Apparatus ....... 39

Figure 7. Schematic of ASTM El62 . . . . . . . . . . 40

Figure 8. Flame Spread Rate, $V^{-1 / 2}$, as a Function of External Incident Flux Using ISO Apparatus . . . . . . 41

Figure 9. Flame Spread Rate, $\mathrm{V}^{-1 / 2}$, as a Function of External Flux Using ISO Apparatus ........... 42

Figure 10. Over-All View of Rate of Heat Release Apparatus, Cone Calorimeter.............. 43

Figure 11. Photograph of Large Scale Fire Test Assembly with Ignition Cribs in Place ............ 44

Figure 12. Description of Instrumentation for Large Scale Solar Glazing Tests ............. 45

Figure 13. Maximum Extent of Flame Spread for Large Scale Solar Glazing Tests ............. 46

Figure 14. Flame Spread Rate for Large Scale Fire Tests of Solar Collector Glazings . . . . . . . . . 47

Figure 15. Incident Energy Profile Along Horizontal Center Line of Large Scale Fire Test Using Polycarbonate, PC, Glazing ................... 48

Figure 16. Incident Energy Profile Along Horizontal Center Line of Large Scale Fire Test Using Glass Fiber Reinforced Plastic, GRP-2, Glazing . . . . . . 49

Figure 17. Incident Energy Profile Along Horizontal Center Line of Large Scale Fire Test Using Glass Fiber Reinforced Plastic, GRP-1, Glazing ....... 50 
Figure 18. Incident Energy Profile Along Horizontal Center Line of Large Scale Fire Test Using PMMA

Glazing ............. . . 51

Figure 19. Flame Spread Rate and Wind Speed for Large Scale

Fire Test Using Polycarbonate, PC, Glazing . . . 52

Figure 20. Flame Spread Rate and Wind Speed for Large Scale

Fire Test Using GRP-2 Glazing . . . . . . . 53

Figure 21. Flame Spread Rate and Wind Speed for Large Scale

Fire Test Using GRP-1 Glazing . . . . . . . 54

Figure 22. Flame Spread Rate and Wind Speed for Large Scale

Fire Test Using PMMA Glazing . . . . . . 55 
FLANE SPREAD ON COMBUSTIBLE SOLAR COLLECTOR GLAZING MATERIALS

Emil Braun

Paula J. Allen

Abstract

The use of ASTM D635 and associated criteria as an evaluation method for solar collector glazings was investigated. Four materials commonly used in solar collector applications were evaluated by ASTM D635. Four other test methods were used to characterize the glazing materials as to 1gnition, flame spread, and heat release rate. These results were compared to large scale fire tests of these materials. Based on the large scale tests, it was found that ASTM D635 produced test results that were not consistent with those obtained from the large scale tests.

Good agreement was found between the rank ordering of the large scale tests and heat release rate and ignition properties as measured in the cone calorimeter and modified ISO test.

Key words: ASTM D635; fire test; flame spread; glazing materials; 1gnition; large scale fire tests; rate of heat release; small scale fire tests; solar collectors.

\section{INTRODUCTION}

The design and construction of bulldings are controlled by local and national building codes. These codes attempt to ensure that a safe and durable structure is assembled. The codes mandate that building designs comply with specific structural and fire requirements. With the increased use of solar collectors, concern has been directed towards ascertaining the 1mpact solar collectors have on the fire performance of the entire roof assembly. Solar collectors made of combustible components could provide a path for rapld flame spread from one area of a roof to another area. The flre hazard assoclated with roof mounted solar collectors include the combustibility of materials used in the construction of the collector 1tself (1.e., plpes, 
glazing, casing, absorber plate, insulation), the transfer fluids, and the construction of the roof assembly (i.e., roofing material and insulation).

Model building codes $[1,2,3]^{1}$ utilize ASTM D635 [4] as one of the test methods for classifying plastic wall and roof panels. Based on this classification, maximum permitted areas are defined for each occupancy group. Requirements [5,6] for roof mounted solar collectors use the same test method and classification system to evaluate the acceptability of plastic covers on solar collectors. The Uniform Building Code [6] specifies that for buildings not over three stories in height or $836 \mathrm{~m}^{2}\left(9,000 \mathrm{ft}^{2}\right)$ in total floor area combustible glazings whose thickness exceeds $0.254 \mathrm{~mm}(0.01$ inch) are limited to:

Classification

$\mathrm{CC} 1$

$\mathrm{CC} 2$
Percent of Roof Area

$331 / 3$

25

For plastic glazing less than $0.254 \mathrm{~mm}$ ( 0.010 inch) thick, any plastic may be used provided the area of the collectors does not exceed $331 / 3$ percent of the total roof area.

A correlation between D635 and actual fire performance has not yet been established. It was the purpose of this study to evaluate the flame spread characteristics of combustible solar collector glazing materials and compare smal1-scale fire measurements to large scale fire performance. The candidate materials were subjected to the five small scale tests listed below.

\section{Small Scale Tests}

Test Name

ASTM D635

Ease of Ignition Test Modified ISO apparatus

ASTM E162

Cone calorimeter $\underline{\text { Measurement }}$

Rate or extent of burning

Time-to-flame attachment

Ignition time

Flame spread rate

Flame spread index

Ignition time

Rate of heat release

1 Figures in brackets indicate literature references at the end of this report. 
These tests measured several fire properties that were useful in characterizing combustible glazing materials. It was assumed that the glazing material would not be the first item ignited. Ignition and flame spread along combustible solar glazing material would be driven by the presence of an existing fire in close proximity to a solar collector system. With the exception of ASTM D635, all of the test methods used to characterize these materials evaluate fire performance under conditions of an externally imposed heat flux. Since no test method directly simulated end use conditions, ignition and flame spread test methods were selected that varied in:

\footnotetext{
1. sample mounting geometry;

2. sample size;

3. level of incident energy;

4. ignition mechanism.
}

Each glazing material was also evaluated in a large scale fire test of a simulated roof assembly with directly mounted flat plate solar collectors. These tests were designed to determine material response to an existing fire occurring adjacent to a solar collector system. Large scale and small scale test results were analyzed for correlation factors.

\section{BACKGROUND}

\subsection{Solar Collector Fires and Performance Requirements}

A recent fire incident involving a newly installed solar collector system $[7,8]$ dramatizes the complex nature of evaluating the fire risk associated with solar collector systems. Such a system is a multi-component assembly. Its fire performance is dependent on the interaction of the component parts upon exposure to a fire environment. The case cited involved the self-heating of collector and roofing materials caused by the stagnation heating of the solar collector system. This incident has led to work [9,10] 1nvest1gat1ng low temperature, long term exposure of collector and roofing materials.

Some work has been done on component evaluation specifically almed at solar collector applications. Most notably, Lee and Walton [11] conducted 
fire experiments on solar heat transfer liquids and developed a flash point criteria for the selection of appropriate system fluids.

In general, building codes classify roof finishing materials by their performance in ASTM E108 [22]. This test method determines the fire characteristics of roof coverings when exposed to fires originating outside of the building on which they are installed. Glazing materials used in solar collectors are evaluated by ASTM D635 [4]. In an attempt to bridge this gap, Walton and Waksman [12] conducted a series of E108 tests on actual solar collectors. Their tests involved three types of glazings; tempered glass, glass fiber reinforced plastic, and poly(methyl methacrylate) (PMMA). With regard to surface flame spread, they observed that flame spread on the PMMA glazing was greater than on the roof covering material, and that glass fiber reinforced plastic glazing exhibited more rapid flame spread than PMMA. However, since they were using actual solar collectors, the collectors varied in design and construction as well as the glazing material. It is, therefore, difficult to attribute collector fire performance to one specific component.

\subsection{Flame Spread}

The basic understanding of the phenomenon of flame spread is currently being developed. While three modes of heat transfer are possible (conduction, convection, and radiation), the dominant mode is determined, in large part, by the geometry of the sample, the direction of flame propagation and the direction and magnitude of airflow. Several combinations of the above have recently been investigated resulting in the development of empirical models for predicting flame spread rate across a combustible solid. The chemical and physical phenomena governing flame spread over the surface of combustible solids have recently been reviewed by Fernandez-Pello and Hirano [13].

Flame spread in large scale fires is predominantly controlled by radiation feedback from the flame. It would be expected that this would also be valid for full scale solar collector fire tests. A theory of radiatively driven flame spread was formulated by Rockett [14]. 
Quintiere [15] has recently developed an improved test method based on that theory, configured for vertically oriented samples with horizontal, against-the-wind flame spread. The analysis relates $V_{f}$, the rate of flame spread, to $\dot{q}_{e}^{\prime \prime}$, the external imposed flux and to two material constants, $C$ and $\dot{q}_{0, i g}^{\prime}$ :

$$
v_{f}^{-0.5}=c\left(\dot{q}_{o, i g}^{\prime \prime}-\dot{q}_{e}^{\prime \prime}\right)
$$

where $\quad C=a$ derived material constant

$$
\dot{q}_{0, i g}^{\prime \prime}=\text { minimum flux for piloted ignition. }
$$

The flame rate coefficient, $C$, is a function of flame transfer distance, rate of heat transfer from the flame, and thermal properties of the substrate (thermal diffusivity, thermal conductivity, and heat transfer coefficient). This relationship is applicable to against-the-wind flame spread on a specimen thermally equilibrated to an external (non-zero) radiant flux field prior to ignition.

The translation of laboratory measurements of $C$ and $\dot{q}_{0, i g}^{\prime \prime}$ to predictions of full-scale flame spread has not yet been systematized. It was, indeed, an objective of this study to see if such a relationship could be observed.

\section{TEST MATERIALS}

A total of seven materials were selected for laboratory evaluation. Four samples were representative of glazing materials suitable for solar collector applications. Two types of roofing shingles common to the building industry and a fiberboard sample with uniform physical and fire characterlstics were included.

\subsection{Dimensional Properties}

Table 1 is a tabulation of material identification, thickness, and density. The glazing materials had a thickness range of 1 to $1.6 \mathrm{~mm}$, while 
the roofing shingles were approximately twice as thick. The fiberboard sample was four to six times as thick as any glazing material. The poly(methyl methacrylate) (PMMA) and the polycarbonate were the thickest of the glazing samples. The two glass fiber reinforced plastic samples were the thinnest materials evaluated.

Material density varied from $900 \mathrm{~kg} / \mathrm{m}^{3}$ fiberboard to $1780 \mathrm{~kg} / \mathrm{m}^{3}$ fiber glass shingles. While PMMA and polycarbonate (PC) samples were the thickest glazing materials, they had the lowest density:1350 kg/m and $1220 \mathrm{~kg} / \mathrm{m}^{3}$, respectively. The fiber glass shingles had an ASTM El08 rating of Class A, while asphalt shingles where rated Class $\mathrm{C}$.

\subsection{Fire Properties}

All seven materials were subjected to five small scale fire tests. Two tests measured ignition, two measured flame spread, and one measured the rate of heat release characteristics of the candidate materials. In addition, the samples were classified according to the results obtained from ASTM D635. Ease of ignition, flame spread rate, and heat release rate each provide single property measurements of fire performance. Within the context of a test method, each property measurement is conducted under controlled conditions.

\subsubsection{Bunsen Burner Test}

Solar collector glazings are classified according to the results obtained from ASTM D635. There are two acceptable rating levels, in addition to test failure. A CCl rating implies that the test material did not burn $25.4 \mathrm{~mm}$ beyond the initial mark. A CC2 rating indicates a burning rate less than $1.1 \mathrm{~mm} / \mathrm{s}$. A burning rate in excess of CC2 is unacceptable and not permitted for use in roofing assemblies.

ASTM D635 describes a smal1 scale laboratory screening procedure for comparing the relative rate of burning or extent and time of burning of selfsupporting plastics. A test specimen, $125 \mathrm{~mm}$ long by $12.5 \mathrm{~mm}$ wide by normal thickness, is supported horizontally at one end with its transverse axis inclined at $45^{\circ}$ to the horizontal, Figure 1. A screen of wire gauze is placed 
$10 \mathrm{mn}$ below the lower edge of the specimen such that $13 \mathrm{~mm}$ of the specimen extend beyond the edge of the gauze. A bunsen burner is adjusted so that with air ports open a $25 \mathrm{~mm}$ blue flame is produced. The free end of the sample is exposed to the flame for 30 seconds. The rate of burning is measured over a $75 \mathrm{~mm}$ distance beginning $25 \mathrm{~mm}$ from the exposed edge of the specimen. If the specimen extinguishes before reaching the 100 mm mark, the time to extinguishment and the distance burned are recorded.

Table 2 summarizes the results of tests on seven materials conducted in accordance with ASTM D635. Three materials self-extinguished prior to the termination of the test. The extent of burning was greatest for the polycarbonate sample, $50 \mathrm{~mm}$, and the shortest for one of the glass fiber reinforced plastic (GRP-2), $15 \mathrm{~mm}$. The fiber glass shingles produced an intermediate value of $25 \mathrm{~mm}$. Burning rate values were obtained for the remaining four materials. The values varied from 0.12 to $0.71 \mathrm{~mm} / \mathrm{s}$. The solar collector materials, PMMA and GRP-1, burned approximately five times as fast as the fiberboard and Class $C$ asphalt shingles.

Material classification indicates that there were only two CCl rated materials, glass fiber reinforced plastic, GRP-2 and fiber glass based shingles, FGS. All other materials were rated CC2. No material was found to have a rate of burning in excess of $1.1 \mathrm{~mm} / \mathrm{s}$, which would prevent it from being used on any roof structure.

\subsubsection{Ignition Tests}

Two test methods have recently been developed that measure 1gnition delay of a material when exposed to an external source of energy. The test method developed by Lawson and Parker [16], known as an ease of ignition test, determines the time to flame attachment of a vertically mounted sample exposed to a predetermined flux field from a methane flame. The other test method uses a flame spread apparatus currently under consideration by the International Standards organization (ISO) [17]. Quintiere has modifled the test procedure in order to determine ignition time as a function of incident flux. 
In the ease of ignition test, two parallel vertically oriented specimens, $140 \mathrm{~mm}$ wide by $152 \mathrm{~mm}$ high, are mounted with their outer surfaces facing each other but separated by $50 \mathrm{~mm}$. The facing surfaces of both specimens are exposed to a methane diffusion flame produced by multiported burners located below each mounted specimen. Methane gas is initially ignited by an electrical spark igniter also located below the specimens but in the gas stream. A stablized flame extends approximately $150 \mathrm{~mm}$ above the specimens which are mounted in two parallel holders. Figure 2 is a sketch of the ignition apparatus. The burner flame exposure constitutes, on the average, an external flux of $34 \mathrm{~kW} / \mathrm{m}^{2}$ across the specimen surface. The ignition time is defined as the time from initial flame exposure until a flame attaches itself to the surface of a specimen.

A schematic of the ISO apparatus is shown in Figure 3. The apparatus consists of a radiant panel heat source, pilot flame, and sample holder. The radiant source is a porous refractory panel measuring $280 \mathrm{~mm}$ by $483 \mathrm{~mm}$, similar to that employed in the ASTM E162 test apparatus. The sample holder is $155 \mathrm{~mm}$ high by $800 \mathrm{~mm}$ long with a pilot flame located at one end of the sample holder. The radiant panel is positioned over the sample holder so that a nonuniform flux distribution is developed for flame spread measurements.

For the determination of ignition time as a function of incident flux, the fuel-to-air ratio feeding the radiant panel is adjusted to produce a different incident flux. This flux field is nearly uniform over the first 10 $\mathrm{mm}$ of the sample holder. Tests at several incident flux levels are used to determine the minimum incident flux necessary for ignition.

Figures 4, 5, and 6 are plots of ignition time as a function of external flux for all seven materials. Using a method described by Quintiere, it is possible to calculate the minimum incident flux, $\dot{q}_{0, i g}^{\prime \prime}$, necessary for ignition. These are indicated by vertical lines and labeled with the calculated values. A list of $\dot{q}_{0, i g}^{\prime \prime}$ for all seven materials, table 3 , shows that fiber glass shingles and polycarbonate glazing require two to three times more incident flux for ignition than PMMA and fiber glass glazings. 
Table 4 is a comparison of time to flame attachment (TFA) as determined in the ease of ignition test and the time to ignition for the ISO apparatus. Times listed are for an external flux of $34 \mathrm{~kW} / \mathrm{m}^{2}$. The values reported for the ISO apparatus were determined by linear interpolation of the data. No ignition time could be determined for the polycarbonate sample in the ease of ignition test, because it melted and flowed out of the exposure zone. However, ISO results indicate that this material is the most resistant to ignition of the seven materials tested.

Comparisons between the two ignition measurements are remarkable in their similarities. With one exception, ignition times are shorter than TFA, but the rank order of materials are nearly the same. Sample GRP-1, a glass fiber reinforced plastic glazing, has the shortest TFA but an ignition time comparable to the roofing materials, whereas the TFA and ignition time of another glass fiber reinforced plastic, GRP-2, are more consistent with each other.

\section{Comparison of Rank Order of TFA and ISO Ignition Time}

$\underline{\text { TFA }}$

polycarbonate
fiberboard
fiber glass shingles
asphalt shingles
PMMA
GRP-2
GRP-1

Long time

$\begin{array}{ll} & \text { fiberboard } \\ & \text { asphalt shingles } \\ & \text { GRP-1 } \\ & \text { fiber glass shingle } \\ & \text { PMMA } \\ \text { Short time } & \text { GRP-2 }\end{array}$

\subsubsection{Flame Spread Tests}

The surface flammability of materials can be measured by various test methods. Two were selected for the evaluation of surface flame spread of combustible glazing materials.

ASTM E162 [18] was one of the test methods used to evaluate surface flame spread. This test method also provides a laboratory test procedure for measuring and comparing the surface flammability of materials when exposed to 
a varying level of radiant heat flux, however, flame spread is measured horizontally downward. A specimen is exposed to a vertically oriented radiant heat source consisting of a $305 \mathrm{~mm}$ by $457 \mathrm{~mm}$ porous refractory panel, figure 7 . The specimen, $152 \mathrm{~mm}$ by $457 \mathrm{~mm}$, is inclined toward the panel such that ignition is forced by a pilot flame at the high heat flux upper edge. The flame's progress down the specimen is timed. The exhaust stack is equipped with eight thermocouples, which are used for determining the average peak temperature of the exhaust gases. The flame spread index, $I_{S}$, is computed as the product of the flame spread factor, $F_{S}$, and the heat evolution factor, Q:

$$
I_{s}=F_{s} \times Q
$$

Three samples of each material were tested, with the results tabulated in Table 5. The poorest performing material was $\mathrm{PMMA}, \mathrm{I}_{\mathrm{S}}=346$, while the best was fiber glass shingles with an $I_{s}$ of 22. The polycarbonate was nearly as good at 38. The two glass fiber reinforced plastic samples appear to demonstrate large differences in fire performance with $I_{s}$ values of 80 and 199. However, sample GRP-1 exhibited the most erratic burning behavior. The range of $I_{s}$ was 8 to 180 . Based on this, it was not possible to distinguish between the two GRP samples.

A review of the data tabulated in Table 5 shows that the specimens differed substantially in their heat release indices, but only moderately in flame spread values proper.

The previously cited ISO apparatus was used with the radiant panel set to produce a maximum heat flux of $50 \mathrm{~kW} / \mathrm{m}^{2}$ at the location of the pilot flame. This decreased to approximately $2 \mathrm{~kW} / \mathrm{m}^{2}$ at the opposite end. Flame spread data obtained under these conditions were analyzed according to Quintiere's procedure [15]. With this method the data for $\mathrm{V}_{\mathrm{f}}^{-1 / 2}$ are plotted as a function of $\dot{q}_{e}^{\prime \prime}$. Finite flame spread is achieved when $\dot{q}_{0, s}^{\prime \prime}<\dot{q}_{e}^{\prime \prime}<\dot{q}_{0, i g}^{\prime \prime}$ The $\dot{q}_{o, s}^{\prime \prime}$ is the minimum external heat flux required to sustain flame spread and, depending on the material, may be equal to or greater than zero. The $\dot{q}_{o, i g}^{\prime \prime}$ term should have the same value, approximately, as the minimum flux for piloted ignition measured in ignitability tests. Since $\mathrm{v}_{\mathrm{f}}^{-1 / 2}$ is a linear function of $\dot{q}_{\mathrm{e}}$ over the narrow range, $\dot{q}_{0, i g}^{\prime \prime}$ to $\dot{q}_{0, s}^{\prime \prime}$, the slope of the line is the rate coefficient $C$. 
Figures 8 and 9 are plots of $\mathrm{V}_{\mathrm{f}}^{-1 / 2}$ as a function of external incident flux with $\dot{q}_{0, s}^{\prime}$ labeled. Using $\dot{q}_{o, s}^{\prime \prime}$ along with the previous data, the rate coefficients, $C$, can be computed for all seven samples, Table 6 . For a given flux profile and assuming thermal equilibrium, $C$ determines the maximum flame spread rate. The rate coefficient indicated that the polycarbonate sample, S2, and the glass fiber reinforced plastic, GRP-2, should be approximately comparable, while the other glass fiber reinforced plastic sample, GRP-1, should be better than PMMA, but only marginally worse than samples PC and GRP2. Given $C$ and $V_{f}$, it is possible to calculate [15] an ignition temperature, $\mathrm{T}_{\text {ig }}$, from

$$
v_{f}=\left[\frac{C}{110}\left(T_{i g}-T_{s}\right)\right]^{-2}
$$

where $\mathrm{T}_{\mathbf{S}}$ is an initial uniform temperature of the substrate. These values are also listed in Table 6 and will be useful in evaluating large scale test results. Taken together, the flame spread data measured by $\mathrm{F}_{S}$ (Table 5) and by $C($ Table 6$)$ suggest that all test materials show similar flame spread behavior, to within a factor of two, except for FB, which is substantially better.

\subsubsection{Rate of Heat Release}

A bench-scale rate of heat release calorimeter, has recently been developed based on the oxygen consumption principle [19]. This principle states that the heat released per unit mass oxygen consumed is approximately a constant for a wide range of organic fuels. It has been shown [20] that $13.1 \times 10^{3} \mathrm{~kJ} / \mathrm{kg}$ of oxygen is a representative value for typical combustible materials. The heat release rate is computed from the measurements of mass flow rate and oxygen concentration through the exhaust stack, while the effective heat of combustion can readily be determined by using the heat release rate and the corresponding measured mass loss rate of the sample.

Specimens are mounted in a horizontal, face-up orientation, below a temperature controlled heater, Figure 10. The specimen was $100 \times 100 \mathrm{~mm}$ in size at full sample thickness. The heater was similar to an ISo designed heater [21] with a spark ignitor added to improve ignition repeatab111ty. The 
horizontally mounted heater can be operated over a range of temperatures such that the incident flux on the sample surface can be varied from $10 \mathrm{~kW} / \mathrm{m}^{2}$ to $100 \mathrm{~kW} / \mathrm{m}^{2}$.

The maximum heat release rate, effective heat of combustion, and ignition time are tabulated in Table 7. The maximum heat release rate and effective heat of combustion were obtained directly from a data reduction program. Since the measurements were taken prior to the implementation of an ignition time logging scheme, the ignition time was inferred from the weight loss data. The ignition time was defined as the time from exposure of the sample to the cone heater until the occurance of sensible weight loss. Therefore, these ignition times are approximate. These values, however, are comparable to the values determined from the ISO flame spread apparatus at the same external incident flux.

Ignition time at $25 \mathrm{~kW} / \mathrm{m}^{2}$

Solar Glazing Material

ISO Flame

Spread Test

(s)

PMIA

PC

GRP-1

GRP-2

60$$
44
$$

107
Reference \& Roofing Material ISO Flame Spread Test CONE

(s)

(s)

(s)

127

FB

150

321

FGS

320

120

Except for samples PMMA and PC, the peak heat release rates are all within the range of $215 \mathrm{~kW} / \mathrm{m}^{2}$ to $421 \mathrm{~kW} / \mathrm{m}^{2}$. PMMA has a peak heat release rate one third larger than the other samples. Polycarbonate, PC, would not ignite at $25 \mathrm{~kW} / \mathrm{m}^{2}$. The effective heat of combustion of the roofing shingles were slightly more than the other materials.

Because the polycarbonate would not ignite at $25 \mathrm{~kW} / \mathrm{m}^{2}$, additional tests were conducted on this sample and on PMMA at $50 \mathrm{~kW} / \mathrm{m}^{2}$. As noted below, increasing the external incident flux increased the maximum heat release rate of PMMA by 50 percent. The effective heat of combustion, however, decreased 
by about 30 percent. If all samples increased their heat release rate by 50 percent at $50 \mathrm{~kW} / \mathrm{m}^{2}$, the $880 \mathrm{~kW} / \mathrm{m}^{2}$ recorded for polycarbonate would be very high.

Rate of Heat Release at $50 \mathrm{~kW} / \mathrm{m}^{2}$

\begin{tabular}{lccc}
$\begin{array}{c}\text { Max. Heat } \\
\text { Release Rate } \\
\left(\mathrm{kW} / \mathrm{m}^{2}\right)\end{array}$ & $\begin{array}{c}\text { Effective Heat } \\
\text { of Combustion } \\
(\mathrm{MJ} / \mathrm{kg})\end{array}$ & $\begin{array}{c}\text { Ignition } \\
\text { Time } \\
(\mathrm{s})\end{array}$ \\
\hline PMMA & 1136 & 25 & 20 \\
PC & 880 & 32 & 53 \\
& & &
\end{tabular}

Four large scale outdoor tests were conducted to evaluate flame spread characteristics of combustible solar glazings. The glazings used in these tests were similar to the samples evaluated in the laboratory tests, samples PMMA, PC, GRP-1, and GRP-2. Measurements were made of the extent of flame spread across the glazing and the temperature and heat flux to adjacent surfaces

\subsection{Experimental Design}

A simulated roof section, $2.4 \mathrm{~m}$ wide by $4.8 \mathrm{~m}$ long, was constructed, Figure 11. The roof deck was made from standard steel studs and plywood (nominal $12.7 \mathrm{~mm}$ ) sheets. The plywood was covered with Class A fiber glass shingles, similar to sample FGS except below the simulated solar collectors. Provisions were made for the placement of wood cribs at one end of the structure. The entire structure was placed on a frame support configured to ma1ntain the roof at an inclination of $60^{\circ}$ from the horizontal. The frame support was placed on a wagon to allow for the correct positioning of the test structure relative to prevailing the wind.

A simulated solar collector system was directly mounted on the central portion of the roof deck. The solar collectors were divided into six sections of $0.6 \mathrm{~m}$ by $1.22 \mathrm{~m}$ steel boxes covering a total of $1.22 \mathrm{~m}$ by $3.66 \mathrm{~m}$ of roof 
decking. Each collector box was framed with steel studs and backed by a $1.6 \mathrm{~mm}$ thick steel sheet. The glazing, therefore, was raised $90 \mathrm{~mm}$ above the roof surface. No additional insulation was used in the collector construction in order to eliminate additional design variables. The glazing material was attached to the collector box studs. Wood finishing straps were placed over the glazing edges and also affixed to the box studs.

Three wood cribs placed in an "L" pattern at one end of the roof assembly were used as the source of external energy. Each wood crib was an arrangement of $38 \mathrm{~mm}$ by $38 \mathrm{~mm}$ white pine wood strips with a finished size of $457 \mathrm{~mm}$ by $508 \mathrm{~mm}$ long by $152 \mathrm{~mm}$ wide. Rows of three $508 \mathrm{~mm}$ long strips were alternated with rows of seven $152 \mathrm{~mm}$ strips to a full height of $457 \mathrm{~mm}$. Each wood crib weighed approximately $9 \mathrm{~kg}$. Each crib was placed in a metal pan containing $470 \mathrm{ml}$ of heptane. The heptane was used to rapidly involve the cribs in flanes. This was an attempt to simulate a fully involved roof fire. The cribs were allowed to burn until they self-extinguished.

\subsection{Instrumentation}

The roof assembly was instrumented with thermocouples and total heat flux meters. These monitored the thermal impact of the fire at various locations. Eight thermocouples and five heat flux meters were distributed on the roof assembly as shown in Figure 12. In addition, wind direction and speed were recorded throughout each test.

Type $\mathrm{K}$ thermocouples $0.51 \mathrm{~mm}(20 \mathrm{mil})$ in diameter were surface mounted on the fiber glass shingles, wood straps, and glazing. Gardon type water-cooled heat flux meters were used to measure incident heat flux. They were mounted flush with the surface of the glazing and fiber glass shingles. Wind speed was determined by a calibrated anemometer, while the wind direction was measured by a circular potentiometer. All instruments were connected to a digital data acquisition system that recorded the data on magnetic tape at a fixed time interval of 10 seconds. 


\subsection{Results}

Figure 13 shows the extent of maximum flame spread across the simulated collectors. The darkly shaded area represents the area over which the flame propagated and the lightly shaded area is significant thermal degradation beyond the maximum extent of flame spread. In figure $13 \mathrm{~A}$ and $\mathrm{B}$, fire damage was limited to the first panel adjacent to the fire cribs and approximately one-third of the second panel. Althought figure 13A shows that flame propagation was limited to less than the full area of the first panel, all of the polycarbonate material in that panel was consumed. The material near the top of the panel melted and flowed down into the flame front. Thermal radiation impinging on the second panel distorted and melted it, but flames did not propagate beyond the wood cover strip between panel sections.

The GRP-2 sample evaluated in the second test propagated a flame into the second panel, while GRP-1, figure 13C, exhibited flame propagation into the third panel. Fire damage in these tests exceeded the maximum observed flame spread by only a small amount and, therefore, was not shown in figures $13 \mathrm{~B}$ and c.

The results of PMMA testing is shown in figure 13D. Flames propagated across the entire collector area. When this test ended no glazing material remained on the roof structure. Total burning time of each test, which is the total time of visible flame on the test structure, and the time at which flame propagation stopped, resulting in stationary burning, are listed below.

\begin{tabular}{cccc}
$\begin{array}{c}\text { Test } \\
\text { Number }\end{array}$ & $\begin{array}{c}\text { Specimen } \\
\text { Code }\end{array}$ & $\begin{array}{c}\text { Burn Time } \\
(\mathrm{s})\end{array}$ & $\begin{array}{c}\text { F1ame Spread } \\
\text { Termination } \\
(\mathrm{s})\end{array}$ \\
\hline 1 & PC & 1220 & 305 \\
2 & GRP-2 & 1270 & 525 \\
3 & GRP-1 & 2100 & 1640 \\
4 & PMMA & 1860 & 1600
\end{tabular}


Damage to the roof structure varied for each test. During the polycarbonate test the plywood deck and roof supports ignited because they were not properly shielded from the ignition cribs. This was corrected in subsequent tests. There was only limited damage to the fiber glass shingles. A 1ittle surface melting above the first panel was noted after the test. Similar results were observed with GRP-2, used in the second test. While GRP-1, used in the third test, appeared to have a similar effect on the roof structure, holes charred through the plywood deck were found behind the first panel section. The presence of additional combustibles below the steel bottom sheet of the collector panel or plywood deck could have dramatically altered the test results. During test three, the fiber glass shingles around the first collector panel section ignited. This, however, may have been the result of changes in wind direction. The effects of wind on flame spread will be discussed below. Both GRP materials, when subjected to a thermal load, filled the collector space (i.e., the space formed by the glazing, metal sides, and bottom collector plate) with visible smoke. The smoke moved in advance of the flame front and was most clearly visible in test three, GRP-1.

The PMMA used in the last test had the greatest adverse impact on the roof structure. Flaming of the fiber glass shingles was observed. In addition, with the flames burning on the fourth collector panel section, open flaming of the plywood deck and roof supports occurred behind the first collector panel. These were manually extinguished before the destruction of the roof supports prematurely terminated the test.

Because we were dealing with a large scale structure where the preferred movement of the flame front changes during the test, the flame velocity in any one direction is not a meaningful measure of overall performance. Instead of a linear flame velocity, the rate at which the flame involved the collector surface was computed. Based on test observations and photographs taken at approximtely one minute intervals throughout a test, estimates were made of the area flame spread rate. Figure 14 compares the area velocity for all four tests. Initially, observable flame spread took longer to occur for the polycarbonate sample than the other three glazing materials. All four materials exhibited a high initial velocity. With the exception of the polycarbonate sample, area velocity decreased as a function of time. The high initial 
velocity can be attributed to vertical flame spread. Vertical flame spread, which is normally more rapid than horizontal, occurred under conditions of high external incident energy while lateral flame spread took place under a decreasing external energy field. No lateral flame spread occurred during the test of the polycarbonate sample.

Figures 15 to 18 show the center line incident energy on the surface of the collector glazing for several distances from the wood cribs. The fluctuations in the level of incident energy for a given location was primarily due to variations in the wind speed and direction. These variations affected the burning characteristics of the wood cribs as well as flame spread along the glazing surface. While the initial peaks in figures 15 and 18 at the $0.3 \mathrm{~m}$ location are extremely high, it should be noted that this was undoubtedly due to the melting and collapse of the glazing material around the heat flux meter into the collector cavity. The heat flux meter was, therefore, completely enveloped in flames. This is a mode of exposure for which the heat flux meter was not calibrated. Later readings were probably valid because the flames had progressed away from the rear of the heat flux meter. The second peak seen on figure 15 at the $0.3 \mathrm{~m}$ location was due to increased ventilation around the cribs because prior to this point in time the polycarbonate surface had extinguished. However, the second peak seen on figure 16, at the same locations, was caused by re-ignition of the sample GRP-2, which was the result of a change in wind direction.

The effects of wind speed and direction on flame spread are shown in figures 19 to 22. Figure 20 shows a large increase in flame velocity just prior to extinguishment. This coincided with a rapid increase in wind speed in the direction of flame spread. Visually, re-ignition of the glazing material occurred due to the wind driving the flames from the ignition cribs across the glazing surface. Figures 21 and 22 show what appear to be more subtle effects.

Table 8 is a tabulation of peak values obtained from the instruments located above the simulated collectors on the fiber glass shingles. The 1gnition or non-ignition of the fiber glass shingles covering the roof is noted in table 8. Two tests $(3 \& 4)$ resulted in the ignition of the shingles, while tests 1 and 2 did not cause ignition of the roof covering. 


\section{DISCUSSION}

\subsection{Correlation Between ASTM D635 and Other Tests}

The applicability of ASTM D635 and its associated classification system to controlling the fire risk of combustible roof glazings can be evaluated by comparing either the classification system or test results to other measures of fire performance. By looking only at the classification system, one is implicitly assuming that ASTM D635 is an appropriate method for determining a materials fire performance in end-use applications. With the introduction of new materials, it is necessary to probe deeper into the design of the test method to insure that acceptable materials are not overlooked and, more importantly, that unacceptable materials are not permitted to be used.

According to the classification system used by several building codes the only glazing material meeting the requirements of a class $\mathrm{CCl}$ material was found to be the glass fiber reinforced plastic, GRP-2. This material was tested in the second large scale test. The other glazing materials were in Class CC2. No glazing material failed to meet either requirement. Based on this classification system, sample GRP-2 should perform significantly better, in the other fire properties tests as well as in the large scale tests, than the other three glazing materials. In addition, the remaining three materials should exhibit approximately equivalent fire properties.

A review of the small-scale data indicates that sample GRP-2 did not perform dramatically better than the other samples. In fact, the polycarbonate, PC, appeared to be more resistant to ignition and have a lower flame spread rate than sample GRP-2. From the point of view of fire performance, the PMMA sample was by far the poorest material. It was the easiest to ignite in addition to having the highest flame spread rate. Overall the small scale tests do not show sample GRP-2 to have significantly better fire performance than samples PC and GRP-1. On the other hand, PMMA does appear to be significantly different than the other materials tested. 
A comparison of large scale fire tests shows similar trends. The polycarbonate, and the glass fiber reinforced plastic, GRP-2 were not markedly different from each other, while PMMA was the only material to completely burn the entire length of the simulated roof section. The fire performance of the GRP-1 was in between PMMA and the other two glazing samples.

The major difference between samples PC and GRP-2 was noted in the improved dimensional stability shown by the glass fiber reinforced plastic. The fiber glass substrate remained intact throughout the fire test, while the polycarbonate melted, dripped and flowed into the fire exposing the collector back plate surface to the full thermal load of the external fire. The fiber glass base provided a thermal barrier to fire advance not provided by the polycarbonate sample. This was true for both fiber glass based materials. However, as noted in the third large scale test, the combustibles were seen pyrolyizing off of the unexposed surface of the fiber glass. This can also represent a fire threat. These combustibles can be collected in dead-end spaces and subsequently ignite spreading the fire beyond what might be anticipated by surface flame spread data alone. This may be a more serious problem for passive heating systems, where large wall or roof sections open directly into the living space, than for active solar collectors. While the ablating characteristics of polycarbonate minimize this type of fire hazard in passive systems, the interior of a building is more likely to be exposed to the full thermal load of an external fire.

For traditional roof finfshing materials, this classification system rates fiber glass shingles as $\mathrm{CCl}$ and asphalt shingles as $\mathrm{CC} 2$. While this appears reasonable, the other measures of fire performance indicate a large difference exists among materials classified as CC2.

The test method exposes a small sample of a candidate material to a small short term exposure from a bunsen burner flame. Under these test conditions, external radiation is nil, and the forward radiation from the burning samples minimized. End-use conditions dictate a somewhat different fire environment. The large scale tests indicated the importance of wind direction in controlling the flame spread rate. An increase in wind speed, in the intended direction of flame spread, effectively increased the external radiation 
impinging on the polymer surface. This is equivalent to imposing an external energy field on the sample and testing with forced airflow across the sample.

ASTM D635 results show rates of $0.71 \mathrm{~mm} / \mathrm{s}$ and $0.69 \mathrm{~mm} / \mathrm{s}$ for PMMA, and GRP-1, respectively. While these materials are both in the same material class, large scale tests show a marked difference in flame spread as well as other sma11 scale test results. ASTM D635 test data do show that polycarbonate is different from PMMA and GRP-1 even though they are in the same material class.

\subsection{Evaluation of Bench-Scale to Large-Scale Correlation}

The small number of specimens tested preclude a detailed correlation of bench-scale to large-scale results. It is, however, possible to examine rankordering and, on that basis, suggest which bench-scale tests are desirable and which are poor. The analysis in the previous section already indicated that results obtained from the established test, ASTM D635, does correlate well with other laboratory tests. Rank-ordering of the data for all the tests are shown in Table 9.

Specimens are fully correctly rank-ordered by two procedures: (1) the values of $\dot{q}_{o, i g}^{\prime \prime}$ in the ISO flame spread test, and (2) the values of the peak heat release rate and time to ignition in the cone calorimeter. The ASTM E162 values for $I_{S}$ show only one reversal in rank-ordering, while the value of $C$ in the ISO test shows a reverse ranking. The ease of ignition test does not yield any suitable ordering. These observations indicate that heat release rate measurements (as conducted in the cone calorimeter) or radiant ignition measurements (as determined in the cone calorimeter or in the ignition testing variant of the ISO flame spread apparatus) offer the most promise.

Rate of heat release and ignition time testing requires the specification of incident fluxes. These were somewhat arbitrarily specified in the present study. A systematic evaluation of end-use exposures would be necessary in order to validate the observed correlations at other exposure conditions. 


\section{CONCLUSIONS}

The glazing material used in the design and construction of a solar collector system represents one component of a multicomponent assembly. The selection of any one material could adversely affect the fire performance characteristics of an entire assembly. This, in turn, could degrade the fire properties of a roof structure. At this point in time, ASTM D635 does not appear to correlate with any of the other tests performed and is a less severe evaluation tool for measuring flame spread potential of solar glazing materials. At best, this test method may provide a screening tool useable by the material developer to evaluate products in the laboratory.

For those localities that have fire performance requirements for roof finishing materials, the preferred test method appears to be the large scale roofing test, ASTM E108. It would seem more consistent with current fire design requirements to require comparable testing of solar collectors and roof finishing materials. It should be pointed out, however, that requirements may be necessary for all solar collector components, separately and in combination, before an adequate assessment of potential fire performance can be made. In addition, no correlation currently exists between ASTM E108 and full scale fire tests of solar collector systems. Data currently avallable are unclear as to the ability of ASTM E108 to properly distinguish between acceptable and unacceptable fire performance of solar collector systems.

Evaluation of a number of newer bench scale test procedures showed widely disparate behaviors. Even though the large scale fire environment has an 1mportant flame spread component, a flame spread index, such as Is (ASTM El62) or C (ISO test) was not the most successfully predictive variable. Instead, the heat release rate (cone calorimeter) and the ignitability properties (modified ISO test; cone calorimeter) were found useful. Ease-of-1gnition by flame impingement (ease of ignition test) was not found useful. 


\section{ACKNOWLEDGMENTS}

The authors would like to acknowledge the help of many staff members at

the Center for Fire Research. We appreciate the assistance given by William Bailey, Roy McLane, and David Swanson in the construction of the large scale test structures. For reducing the data from the ISO flame spread apparatus, we thank Margaret Harkleroad. The financial support of the Office of Solar Heat Technologies, Department of Energy, is also gratefully acknowledged. 


\section{REFERENCES}

[1] Light 'Transmitting Plastic Construction, Article 24, Building Officials and Code Adininistrators International, Inc., 1981.

[2] Light-transmitting Plastics, Chapter 26, Southern Building Code Congress International, Inc., Birmingham, Alabama, 1982.

[3] Uniform Building Code Standard No. 52-4, Method of Test for Determining Classification of Approved Light-Transmitting Plastics, International Conference of Building Officials, 1982.

[4] Standard Test Method for Rate of Burning and/or Extent and Time of Burning of Self-Supporting Plastics in a Horizontal Position, ASTM D635-81, American Society for Testing and Materials, Philadelphia, PA (1981).

[5] Recommended Requirements to Code Officials for Solar Heating, Cooling and Hot Water Systems, ANSI/CABO 1.0-198, Council of American Building Officials, Falls Church, Va.

[6] Uniform Building Code, Section 1714, Solar Energy Collectors, International Conference of Building Officials, 1982.

[7] Harvey, C.S., "Fire in a Residential Solar Panel: A Potential National Problem," The International Fire Chief, Vol. 46, No. 9, (Sept. 1980).

[8] Walton, W.D., "Solar Collector Fire Incident Investigation," Nat. Bur. Stand. (U.S.), NBSIR 81-2326; 1981 August. 45 p.

[9] Loftus, J.J., National Bureau of Standards, personal communications.

[10] The Boeing Company, "National Bureau of Standards - Solar Exposure/ Temperature Measurements Flat Plate Solar Collector," No. TR2-5615-8000-039 (1980).

[11] Lee, B.T. and Walton, W.D., "Fire Experiments and Flash Point Criteria for Solar Heat Transfer Liquids," Nat.Bur. Stand. (U.S.), NBSIR 79-1931 1979 November. 40 p.

[12] Walton, W.D. and Waksman, D., "Fire testing of Roof Mounted Solar Collectors by ASTM E-108," Nat. Bur. Stand. (U.S.), NBSIR 81-2344 1981 November. 74 p.

[13] Fernandez-Pello, A.C. and Hirano, T., Controlling Mechanisms of Flame Spread, Combustion Science and Technology, 32, 1-31 (1983).

[14] Rockett, J.A., Mathematical Modeling of Radiant Panel Test Methods, F1re Safety Research, Nat. Bur. Stand.(U.S.) Special Publ. 411; 1973 August. 251 p.

[15] Quintiere, J.G., A Simplified Theory for Generalizing Results from a Radiant Panel Rate of Flame Spread Apparatus," Fire and Materials, Vol. 5, No. 2, 1981 . 
[16] Lawson, J.R. and Parker, W.J., "Development of an East of Ignition Test Using a Flame Exposure," Nat. Bur. Stand. (U.S.) NBSIR 82-2503 1982 June. $64 \mathrm{p}$.

[17] Robertson, A.F., "A Flammability Test Based on Prposed ISo Spread of Flame Test, Third progress report, Intergovernmental Maritime Consultative Organization, IMCO FP/215 (1979).

[18] Standard Method of Test for the Surface Flmmability of Materials Using a Radiant Heat Energy Source, ASTM E162-75, American Society for Testing and Materials, Philadelphia, PA (1982).

[19] Babrauskas, V., "Development of the Cone Calorimeter -- A Bench-Scale Heat Release Rate Apparatus Based on Oxygen Consumption," Nat. Bur. Stand. (U.S.) NBSIR 82-2611, 1982 November. 84 p.

[20] Huggett, C. "Estimation of Rate of Heat Release by Means of Oxygen Consumption Measurements," Fire and Materials, Vol. 4 (1980).

[21] Technical Report ISO/TR 5657-1982 (E), Fire Test Reaction to Fire-Ignitability of Building Materials, International Organization for Standardization (July 1982).

[22] Standard Methods of Fire Tests of Roof Coverings, ASTM E108-80a, American Society for Testing and Materials, Philadelphia, PA (1982). 
TABLE 1

Description of Materials Used in Small-Scale Tests

Sample ID

PMMA

PC

GRP-1

GRP-2

FB

FGS

AS
Type

Poly(methyl methacrylate) - cast

Polycarbonate

Glass fiber reinforced plastic

Glass fiber reinforced plastic

Fiberboard

Fiber glass shingles

Asphalt shingles
Thickness

(mm)

1.59

1.52

1.02

1.14

1570

6.35

900

2.54

1780

3.18

1420 
TABLE 2

Summary of ASTM D635 Test Results

\begin{tabular}{|c|c|c|c|c|}
\hline Sample ID & $\begin{array}{l}\text { Burn Rate } \\
(\mathrm{mm} / \mathrm{s}) \\
\end{array}$ & $\begin{array}{c}\text { Burn Time } \\
(\mathrm{s})\end{array}$ & $\begin{array}{r}\begin{array}{r}\text { Extent of Burn } \\
(\mathrm{mm})\end{array} \\
\end{array}$ & Classification \\
\hline PMMA & 0.71 & & & $\mathrm{CC} 2$ \\
\hline $\mathrm{PC}$ & & 120 & 50 & $\mathrm{CC} 2$ \\
\hline GRP-1 & 0.69 & & & $\mathrm{CC} 2$ \\
\hline GRP-2 & & 10 & 15 & $\mathrm{CC} 1$ \\
\hline FB & 0.12 & & & $\mathrm{CC} 2$ \\
\hline FGS & & 23 & 25 & $\mathrm{CCl}$ \\
\hline AS & 0.15 & & & $\mathrm{CC} 2$ \\
\hline
\end{tabular}




\section{TABLE 3}

A Comparison of Minimum Incident Flux, $q_{0}^{\prime \prime}, i g$,
Necessary for Ignition

Sample ID

PMMA

FB

AS

GRP-1

GRP-2

FGS

PC
Description

Poly (methyl methacrylate)

Fiberboard

Asphalt shingles

Glass fiber reinforced plastic (1.02 mm)

Glass fiber reinforced plastic (1.14 mm)

Fiber glass shingles

Polycarbonate
9.7

14.5

16.0

17.3

23.0

$q^{\prime \prime} \circ, i g$

$\left(\mathrm{kW} / \mathrm{m}^{2}\right)$

8.7

30.0 
TABLE 4

Comparison of Time to Flame Attachment (TFA) for Ease of Ignition Test and Ignition Time for ISO Apparatus at $34 \mathrm{~kW} / \mathrm{m}^{2}$

Sample ID

PMMA

PC

GRP-1

GRP-2

FB

FGS

AS
TFA

(s)

62

$--($ a)

35

47

106

101

85
ISO

(s)

30

290

67

29

0.6

0.9

0.6

69

Ratio

ISO/TFA

0.5

1.9

95

64

0.8

(a) Could not be tested since specimen melted out of holder prior to ignition. 
TABLE 5 Summary of Test Results Using ASTM E162
Average Values for Three Samples

\begin{tabular}{ccccc} 
Sample ID & F & Q & $I_{S}$ & $\begin{array}{c}\text { Range of } \\
I_{S}\end{array}$ \\
\cline { 2 - 4 } PMA & 10 & 34 & 346 & $317-364$ \\
PC & 7 & 5 & 38 & $13-61$ \\
GRP-1 & 9 & 7 & 80 & $8-180$ \\
GRP-2 & 10 & 19 & 199 & $152-268$ \\
FB & 5 & & & $158-187$ \\
FGS & 7 & 35 & 173 & $1-30$ \\
AS & 11 & 3 & 22 & $149-290$
\end{tabular}

a differences in $F_{S} \times Q$ and $I_{S}$ are due to round off errors 
TABLE 6

Summary of Test Results From the ISO Apparatus

Sample ID

PMMA

PC

GRP-1

GRP-2

FB

FGS

AS $\dot{q}_{0,}^{\prime \prime}$ ig

$\left(\mathrm{kW} / \mathrm{m}^{2}\right)$

8.7

30.0

16.0

17.3

9.7

23.0

14.5 $\dot{q}_{\mathrm{o}, \mathrm{s}}^{\prime \prime}$

$\left(\mathrm{kW} / \mathrm{m}^{2}\right)$

2.5

17.5

12.8

3.5

200

170

500

11.0

330

2.5

260
307

487

$\mathrm{T}_{\text {ig }}$ $\left({ }^{\circ} \mathrm{C}\right)$

289

561

402

419

381 
TABLE 7

\section{Summary of Data Obtained From The Cone Calorimeter} at $25 \mathrm{~kW} / \mathrm{m}^{2}$ and Spark Induced Ignition

Sample ID $\quad \begin{gathered}\text { Maximum Heat } \\ \text { Release Rate } \\ \left(\mathrm{kW} / \mathrm{m}^{2}\right)\end{gathered}$

703

(a)

PC

GRP-1

259

GRP-2

FB

FGS

AS
421

215

314
227
Effective Heat

of Combustion

$(\mathrm{MJ} / \mathrm{kg})$
Ignition

Time

(s)

36

50

28

59

28

81

45

321

44

120

(a) Does not ignite at $25 \mathrm{~kW} / \mathrm{m}^{2}$. 
ํํำ

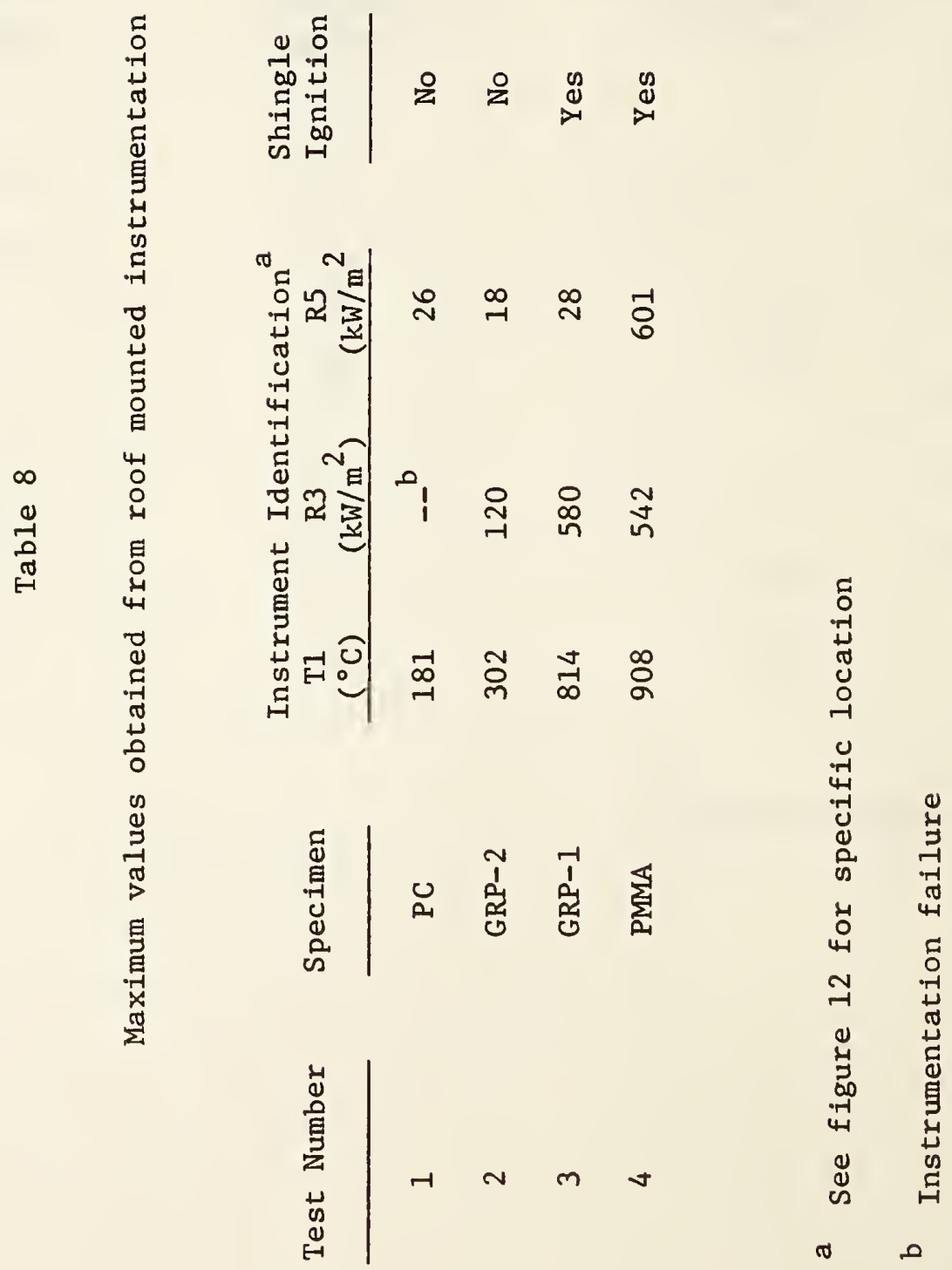




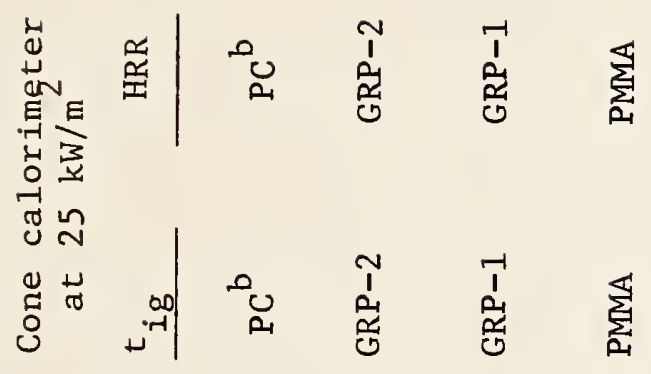

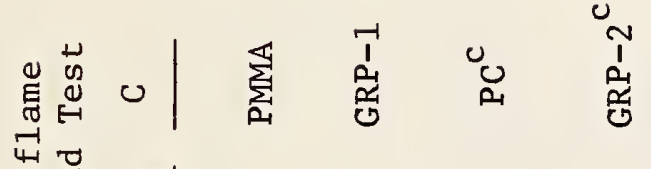

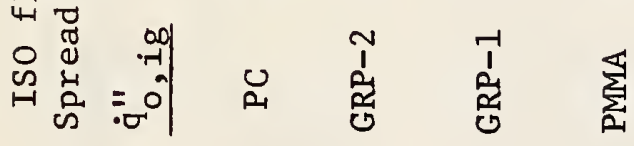

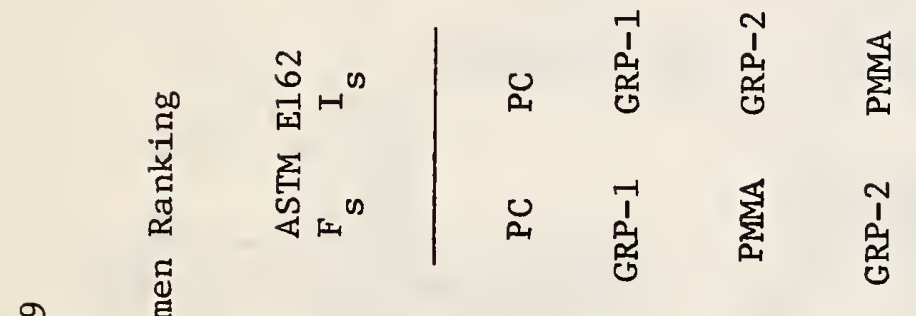

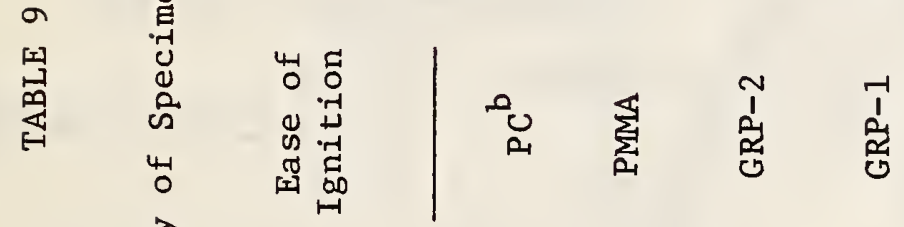

1

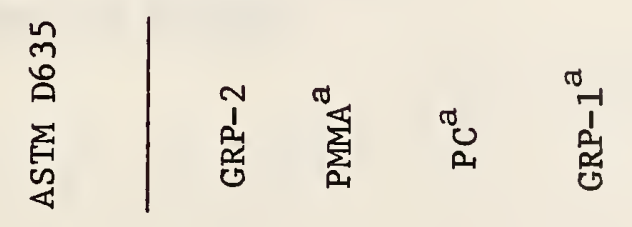

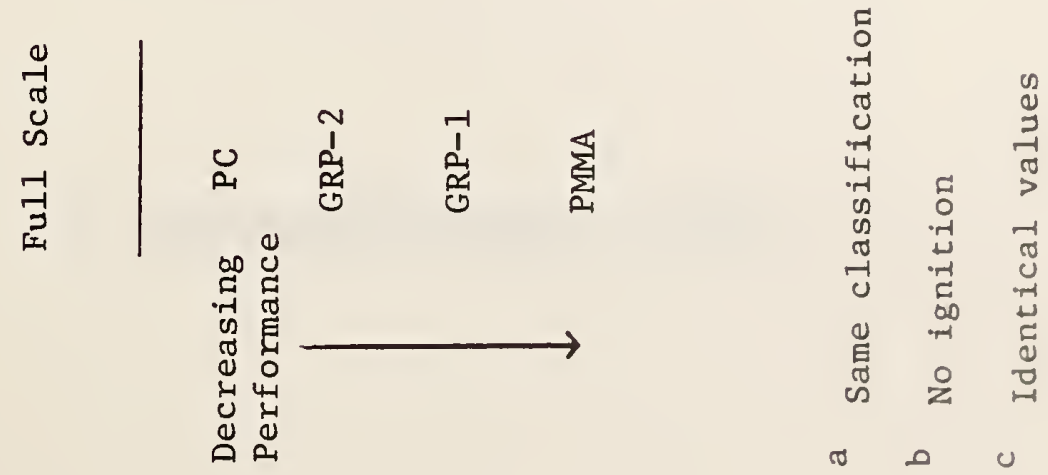




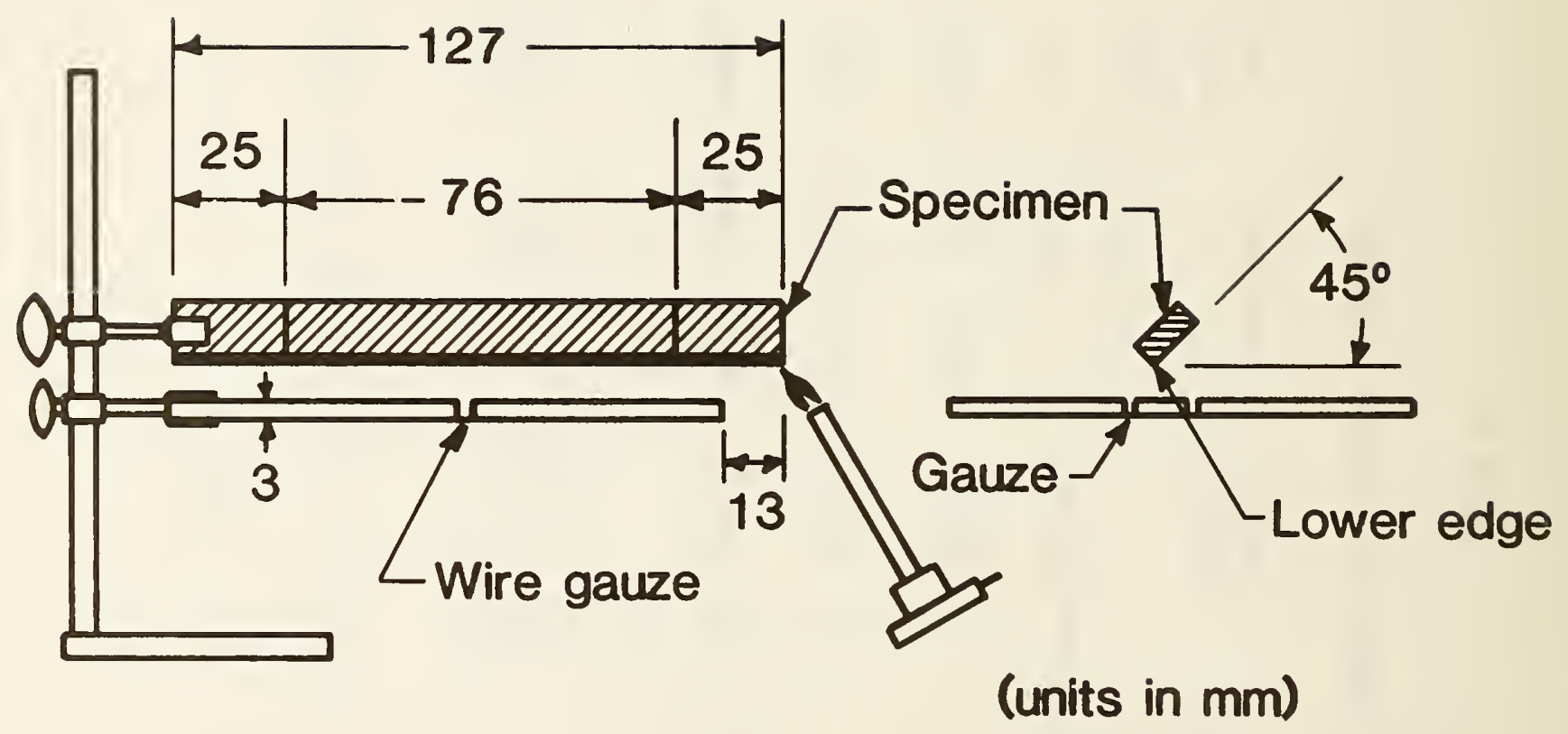

Figure 1. ASTM D635 Apparatus 

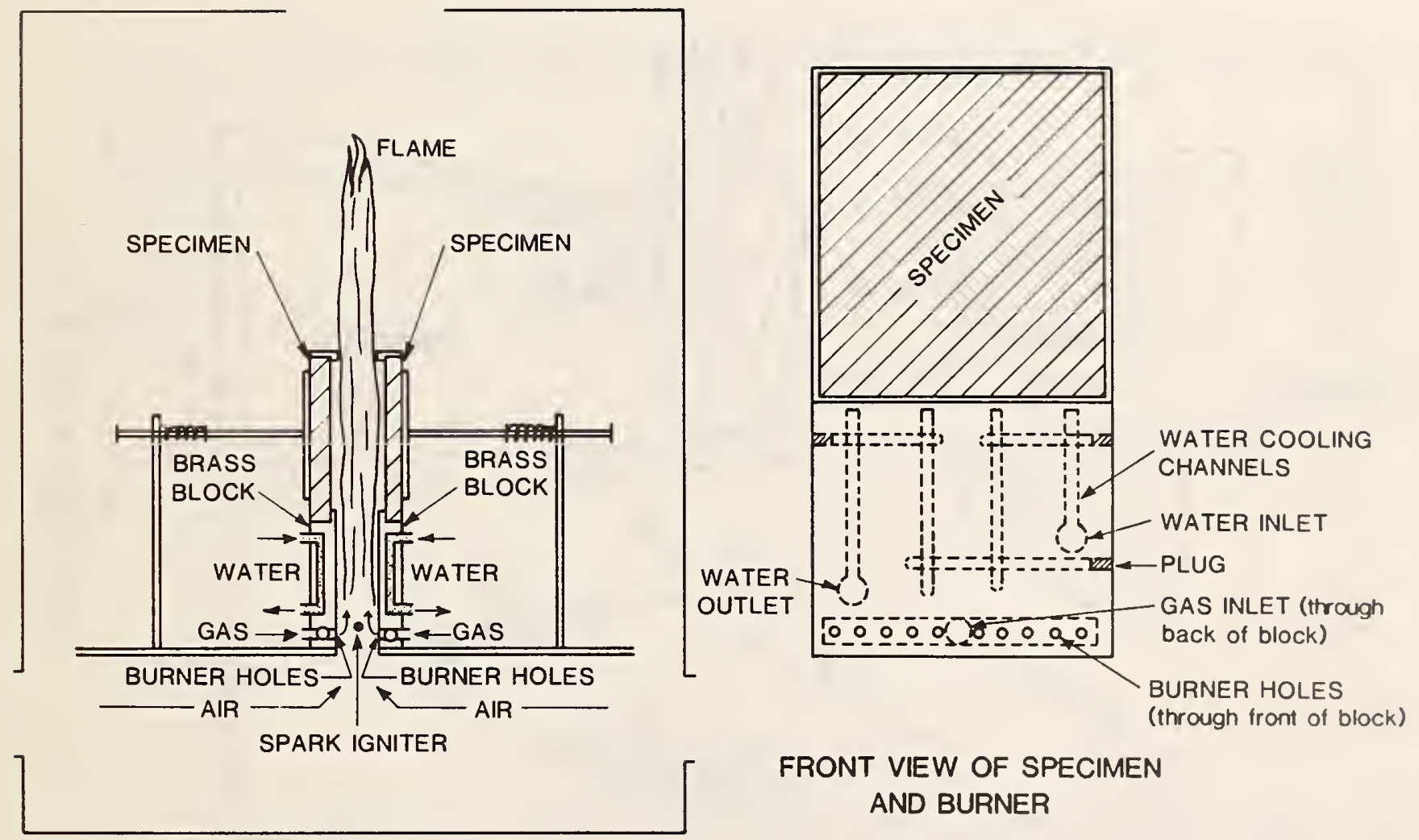

FRONT VIEW OF SPECIMEN

AND BURNER

FRONT VIEW OF APPARATUS

Figure 2. Sketch of Ignition Apparatus 

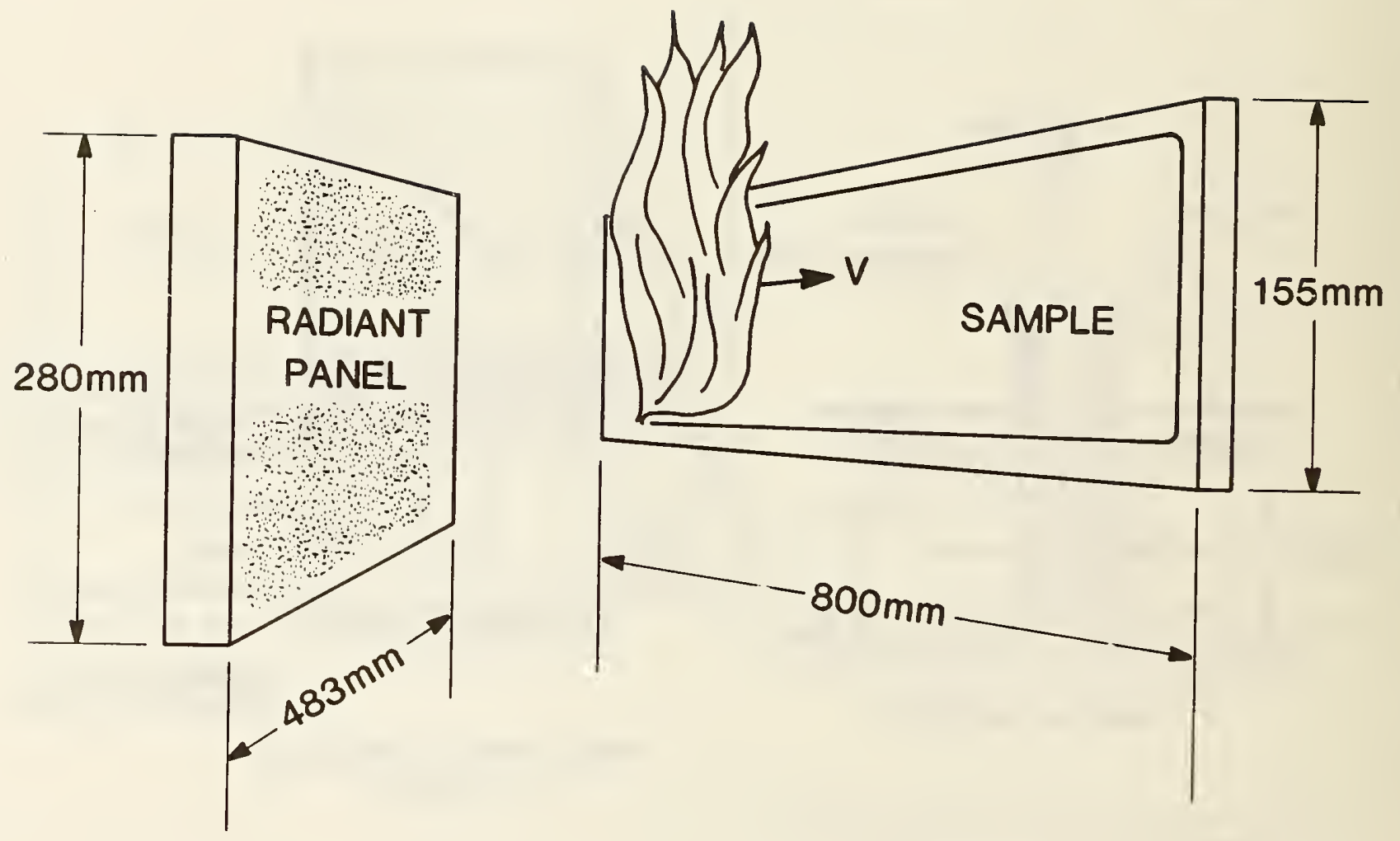

Figure 3. Schematic of ISo Flame Spread Apparatus 


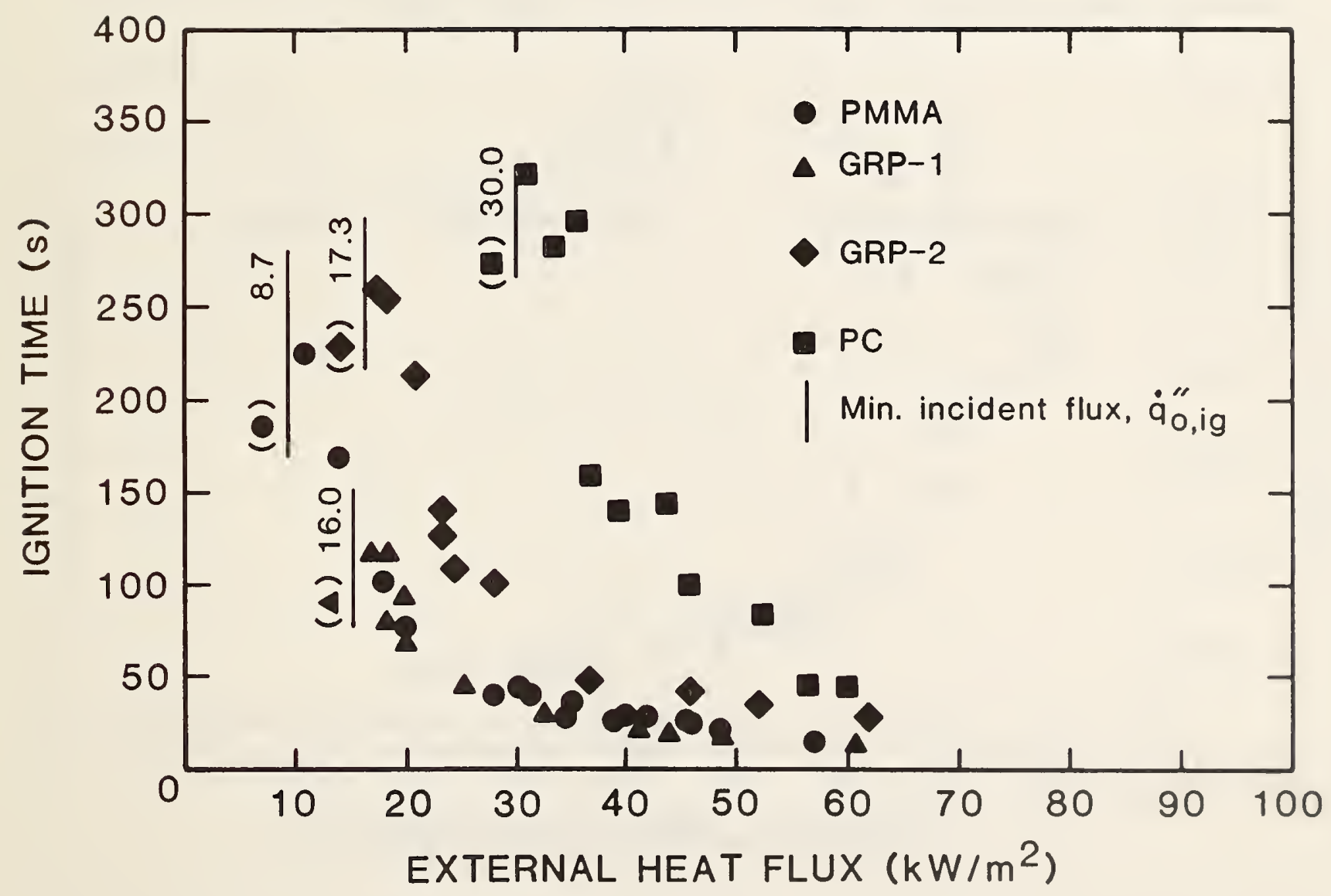

Figure 4. Time for Piloted Ignition as a Function of External Radiant Flux Using ISO Apparatus 


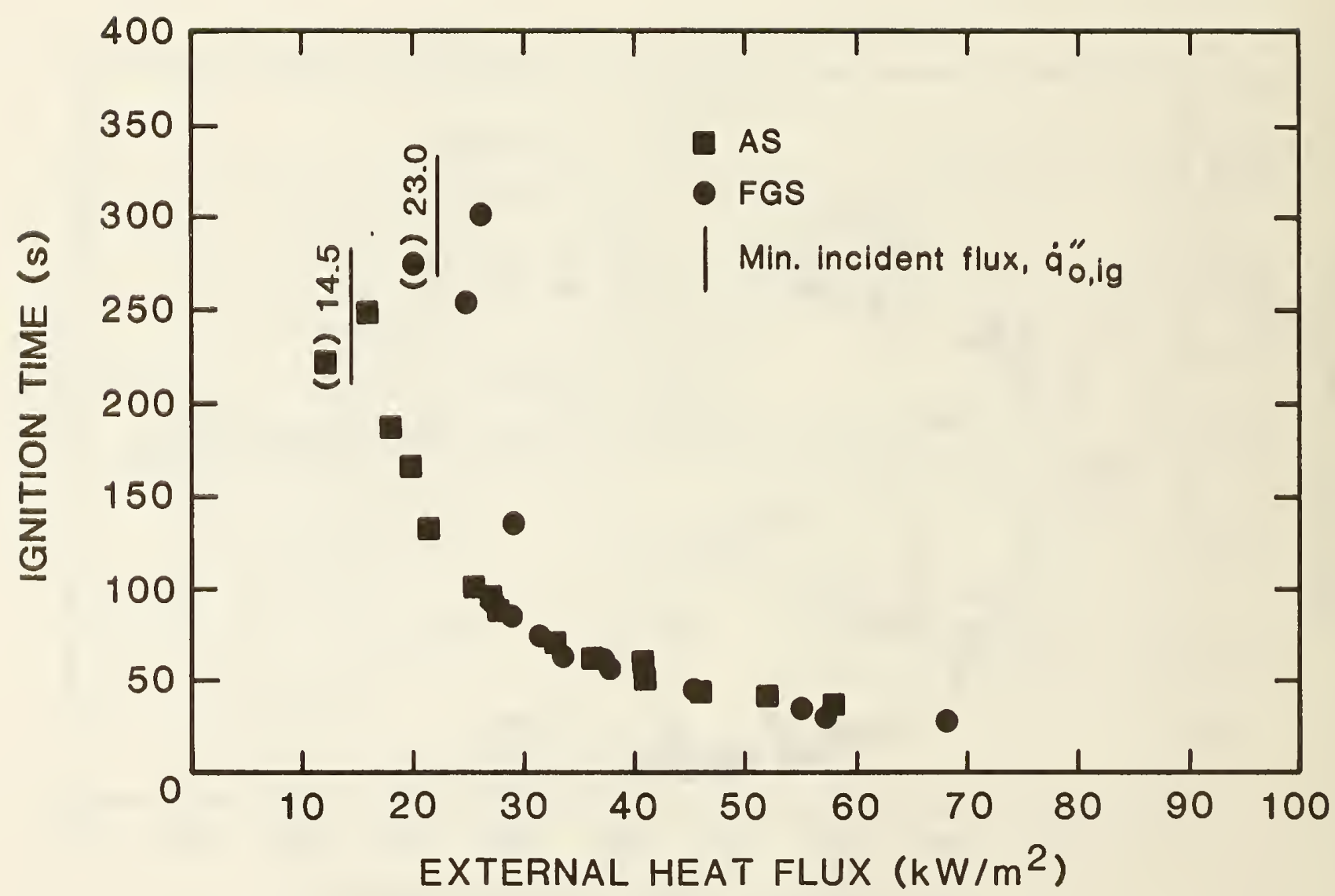

Figure 5. Time for Pilnted Ignition as a Function of External Radiant Flux Using ISO Apparatus 


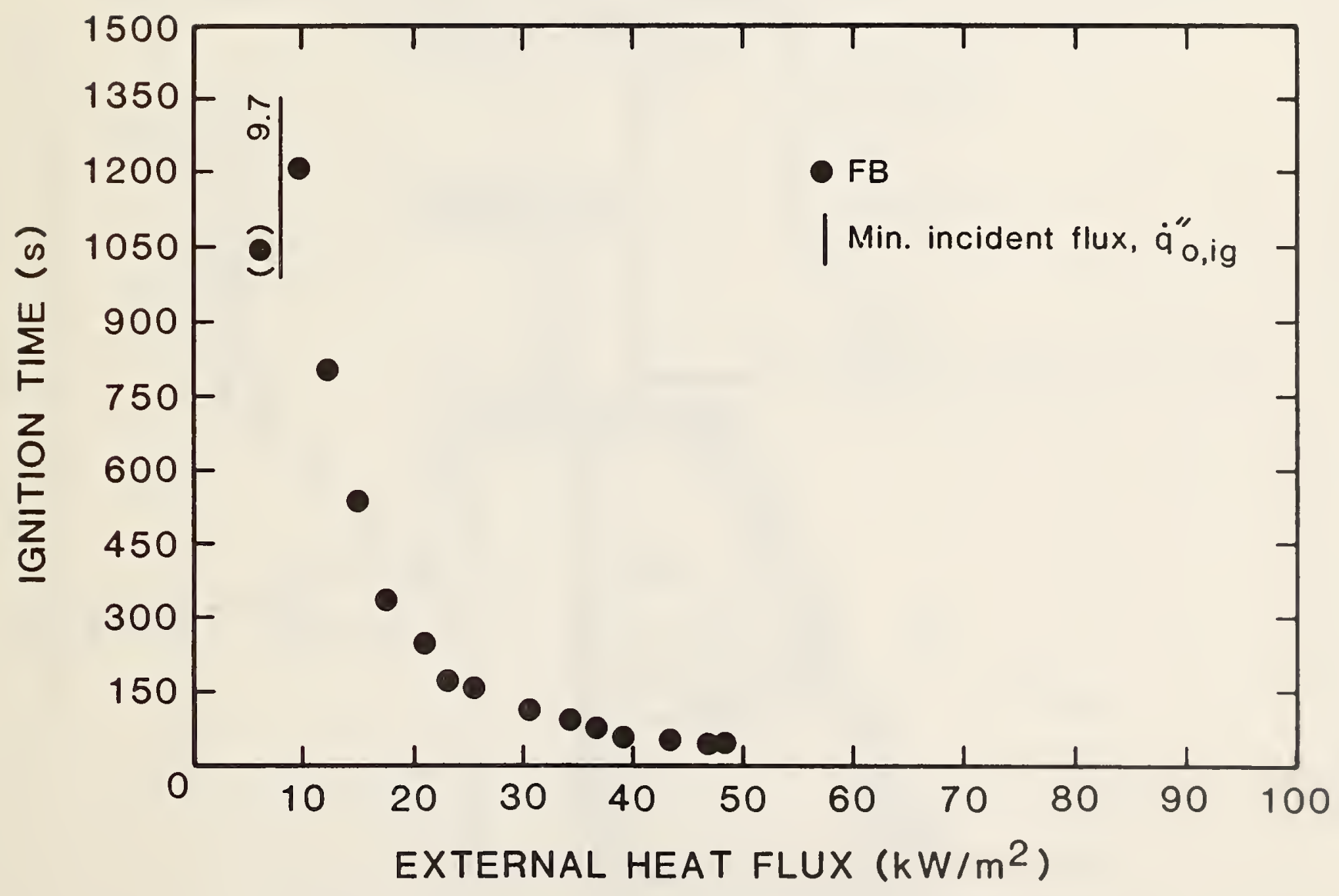

Figure 6. Time for Piloted Ignition as a Function of External Radjant Flux Using ISO Apparatus 


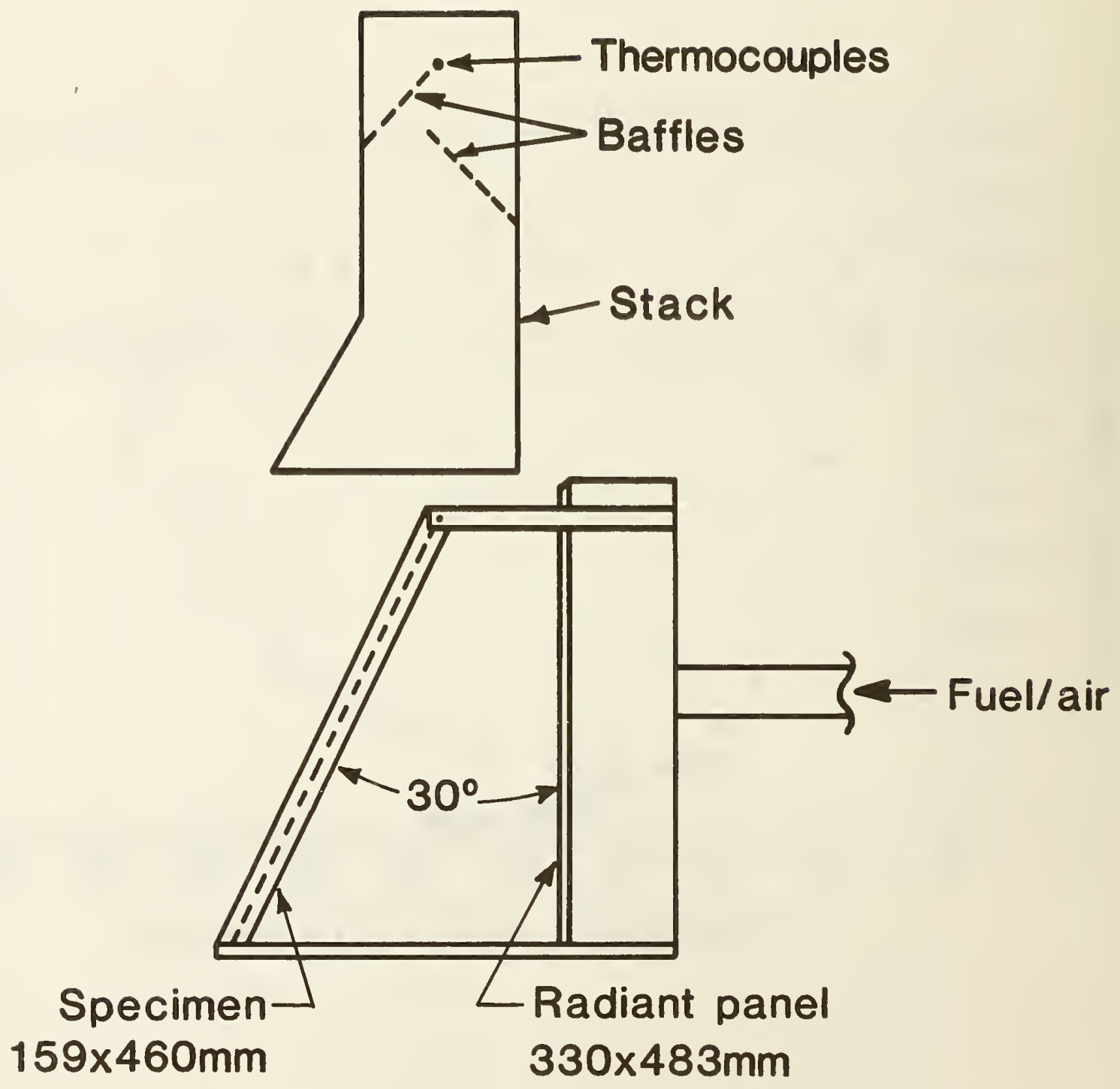

Figure 7. Schematic of ASTM E162 


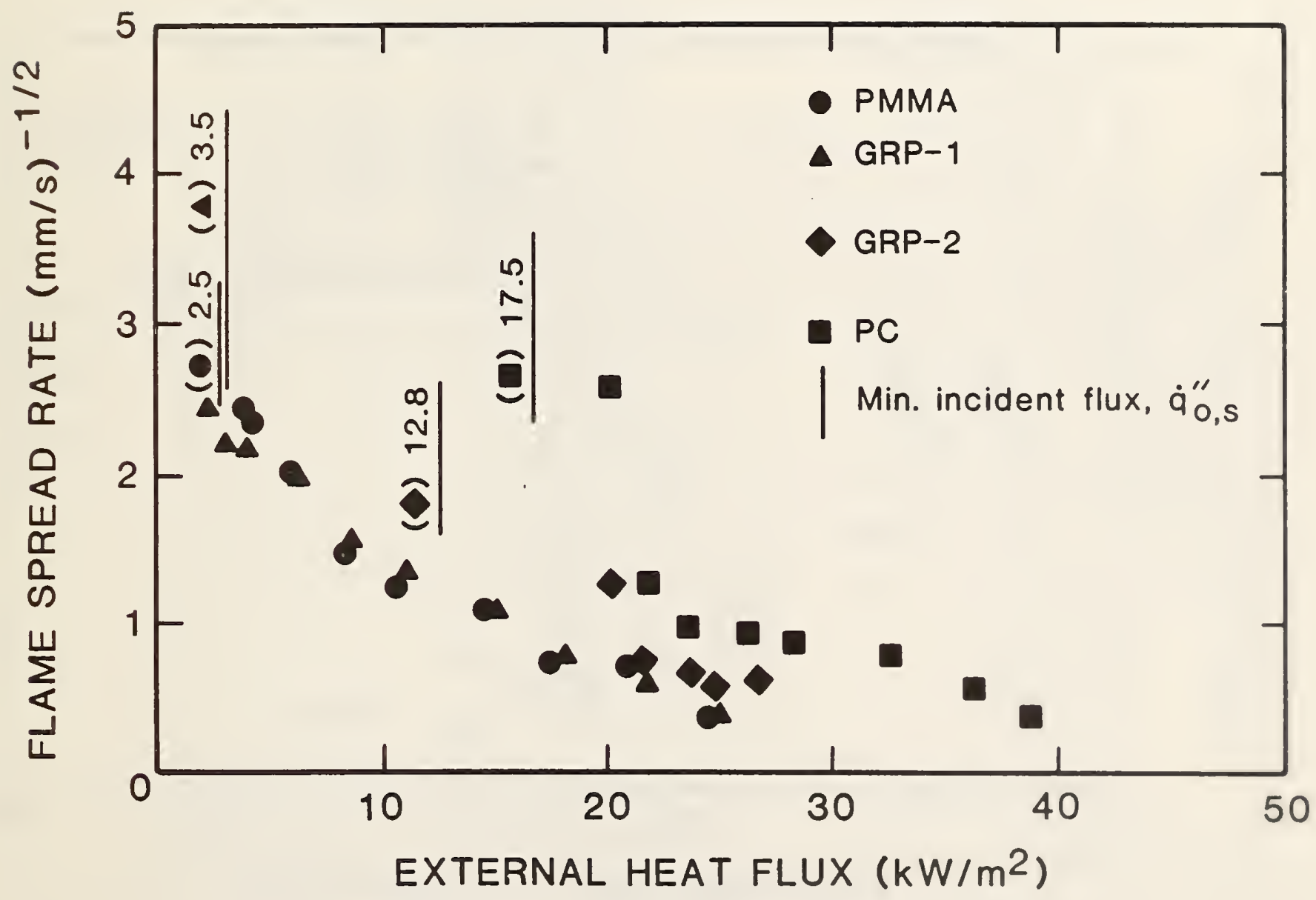

Figure 8. Flame Spread Rate, $V_{S}^{-1 / 2}$, as a Function of External Incident Flux Using ISO Apparatus 


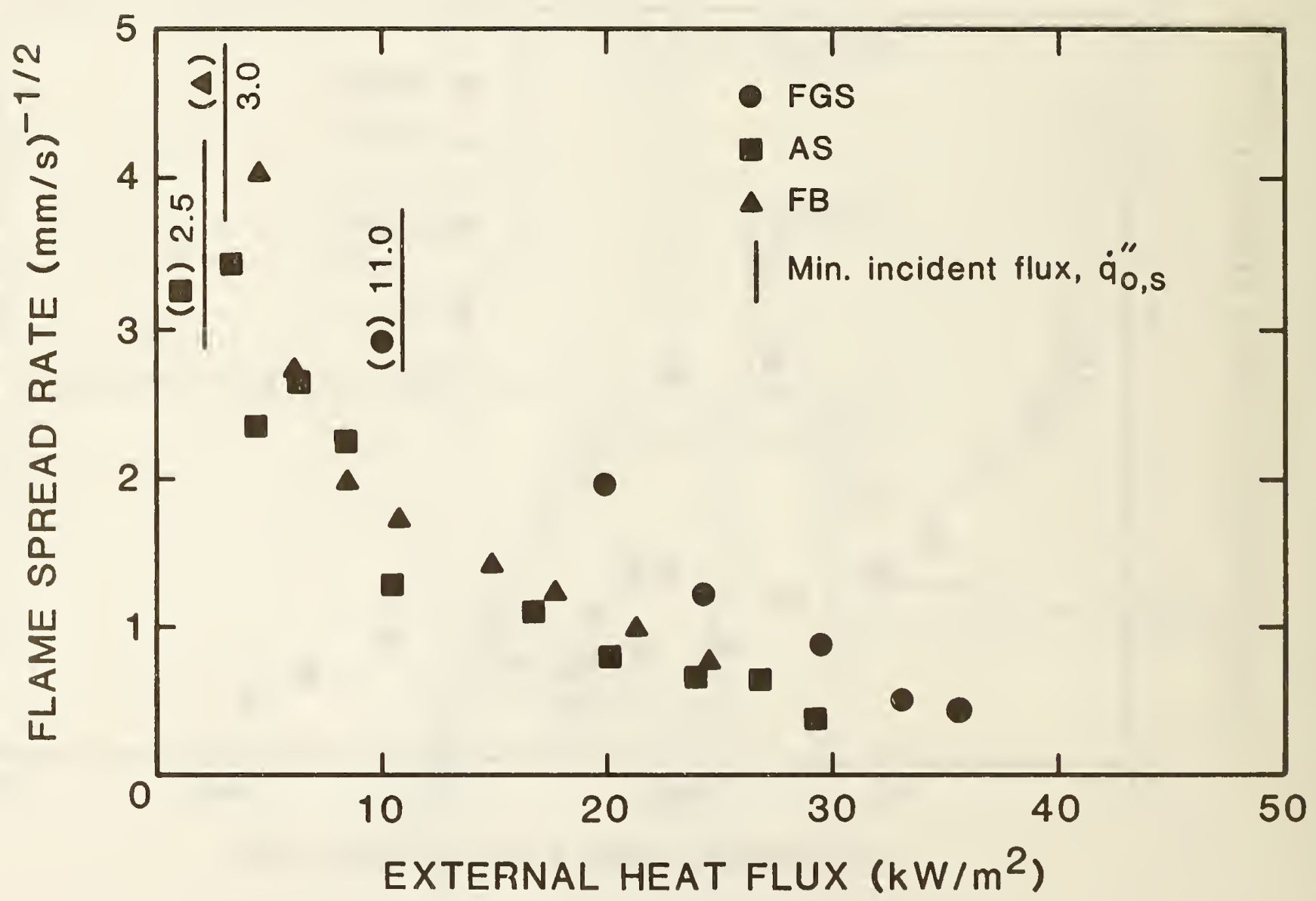

Figure 9. Flame Spread Rate, $V^{-1 / 2}$, as a Function of External Flux Using ISO Apparatus 


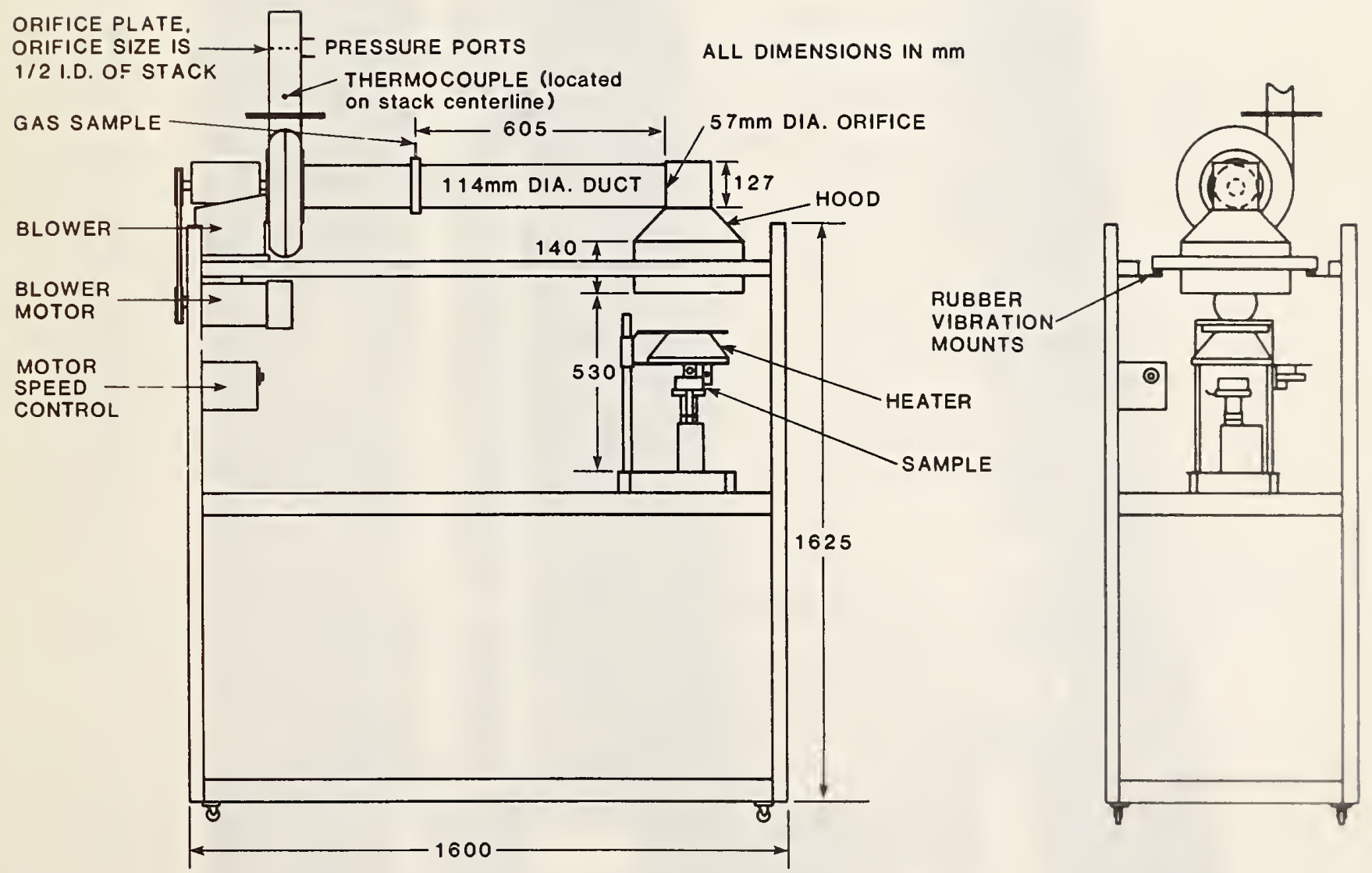

Figure 10. Over-All View of Rate of Heat Release Apparatus, Cone Calorimeter 


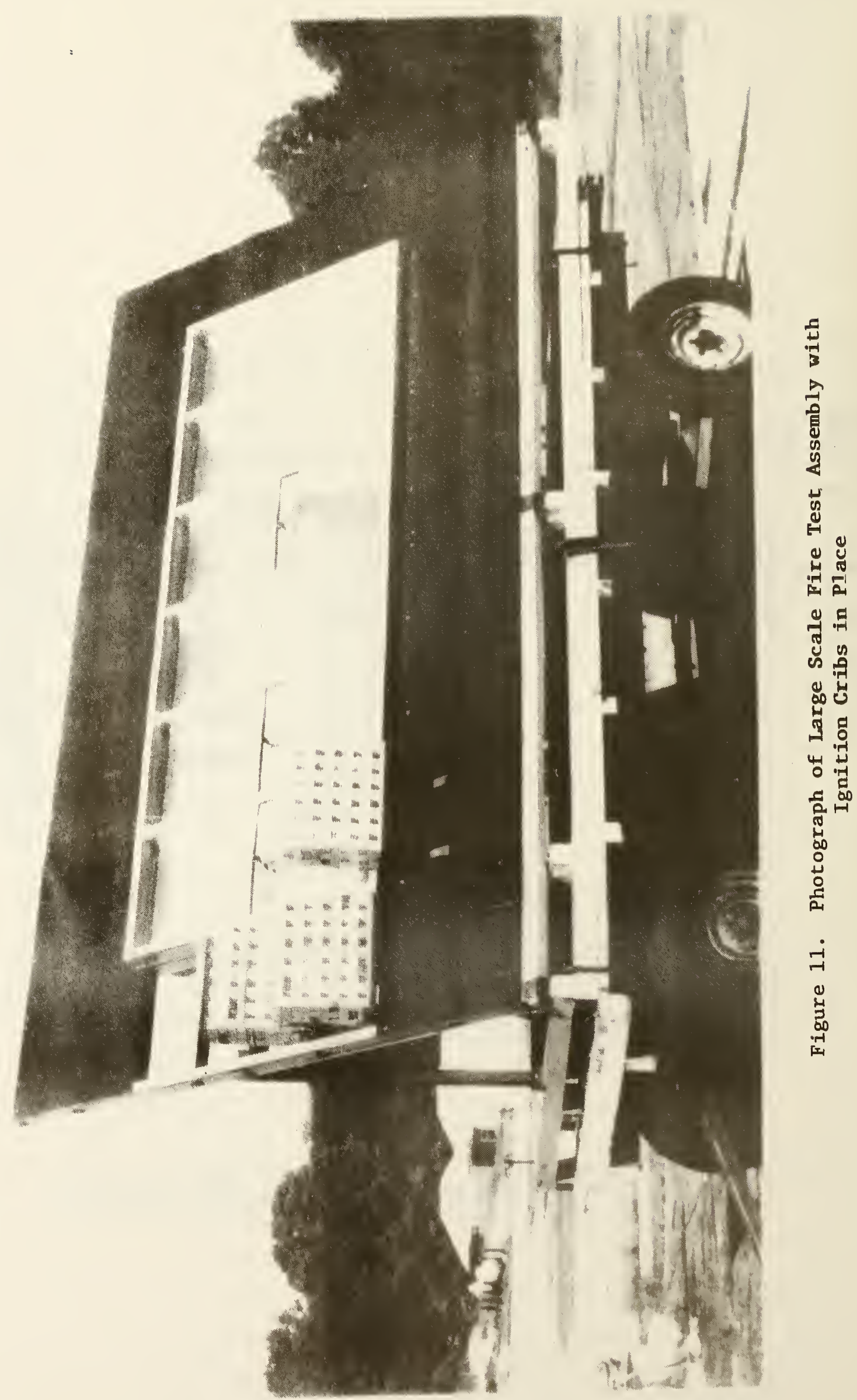




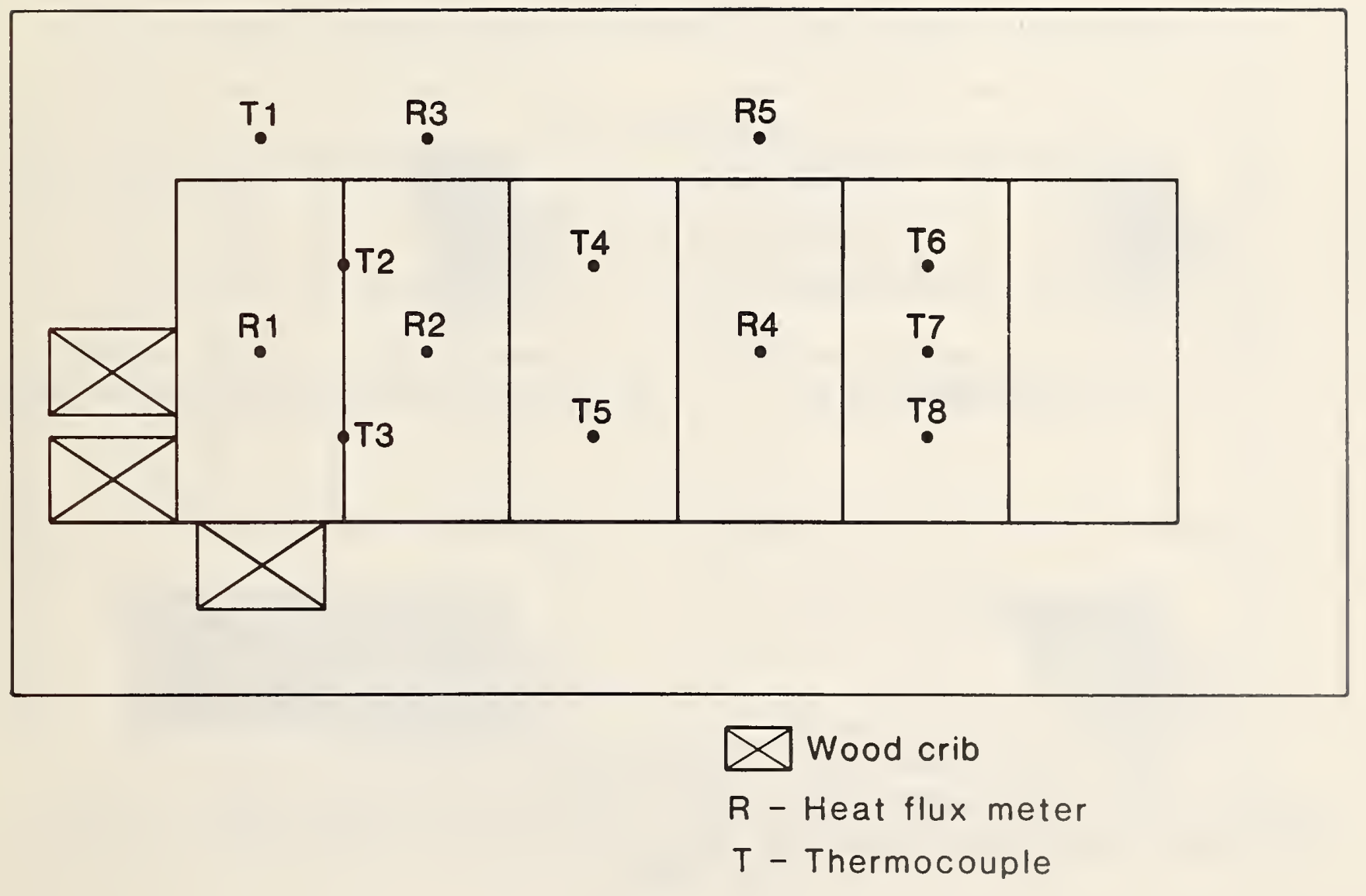

Figure 12. Description of Instrumentation for Large Scale Solar Glazing Tests 


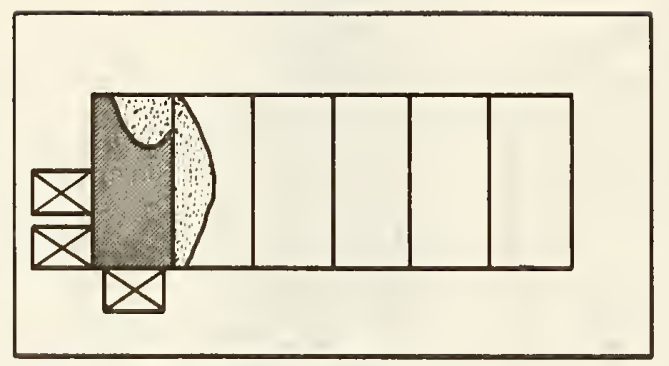

A - POLYCARBONATE, PC

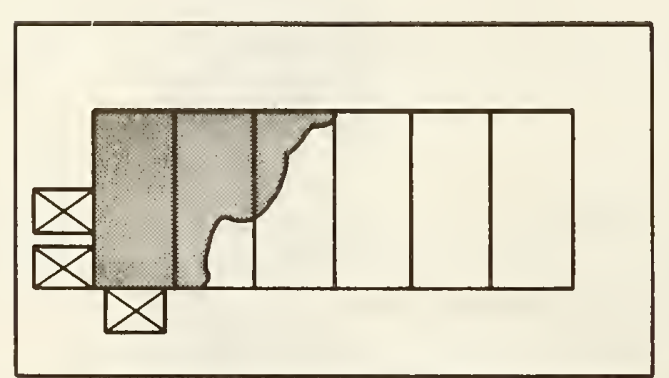

C - PLASTIC REINFORCED FIBERGLASS, GRP-1

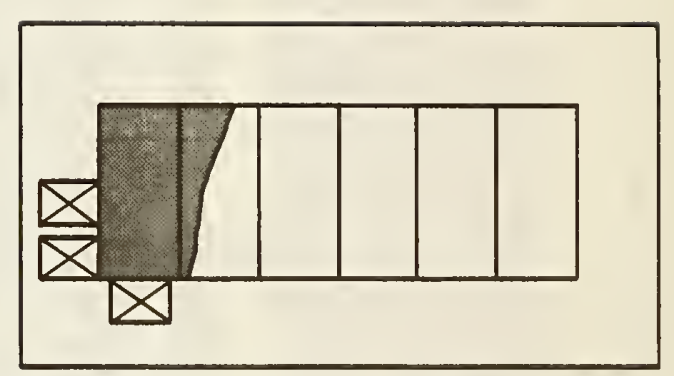

B - PLASTIC REINFORCED FIBERGLASS, GRP-2

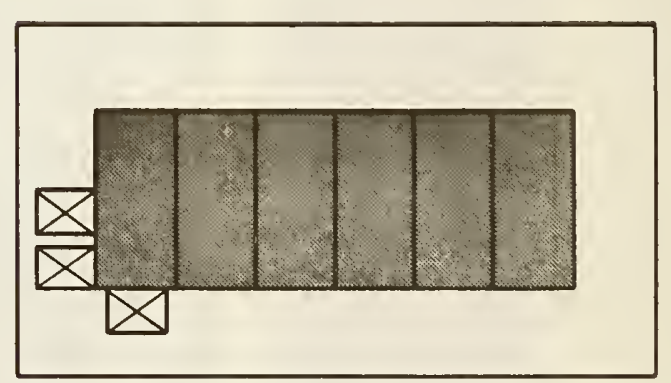

D - POLYMETHELMETHACRYLATE, PMMA

Figure 13. Maximum Extent of Flame Spread for Large Scale Solar Glazing Tests 


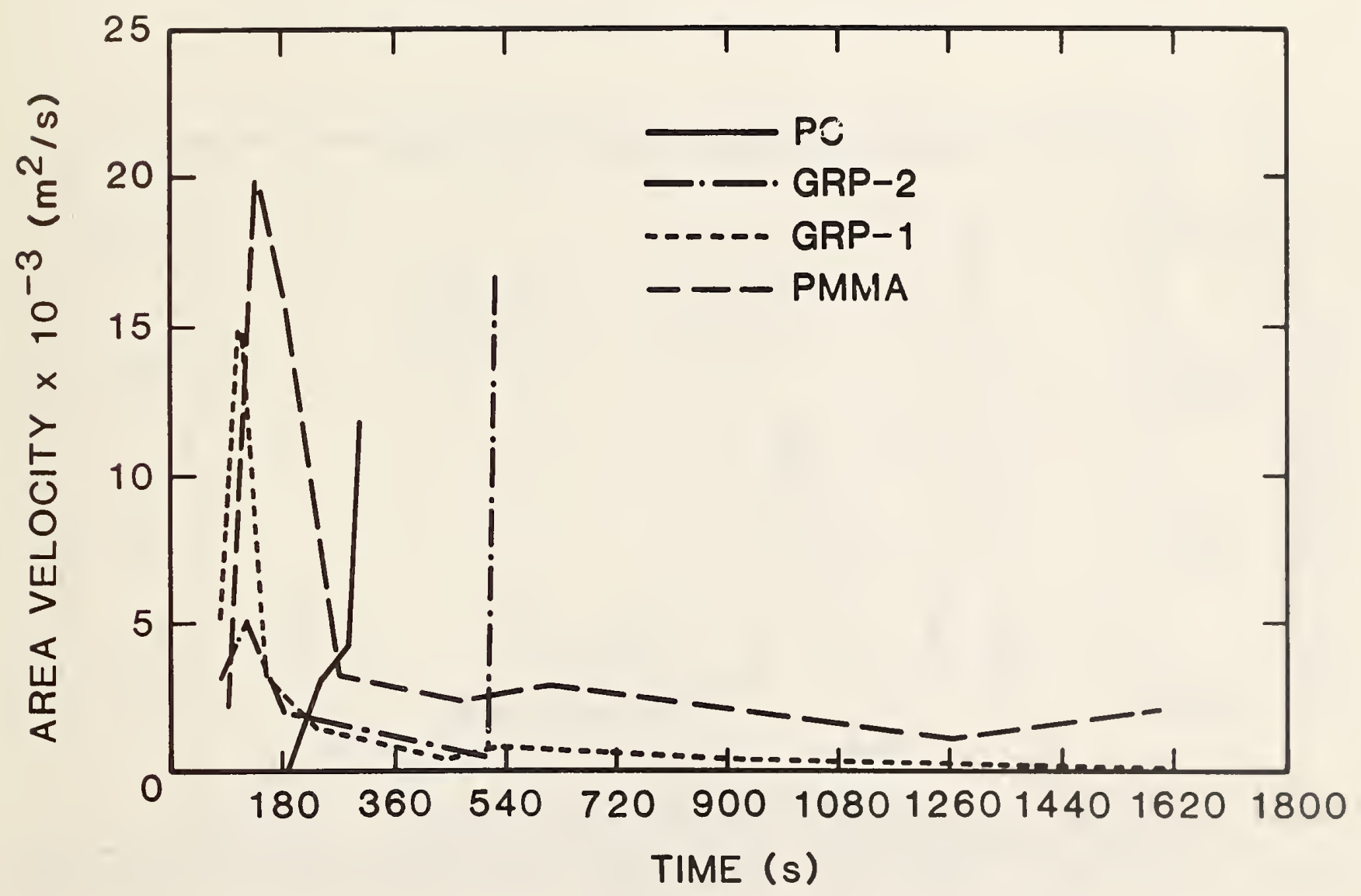

Figure 14. Flame Spread Rate for Large Scale Fire Tests of Solar Collector Glazings 


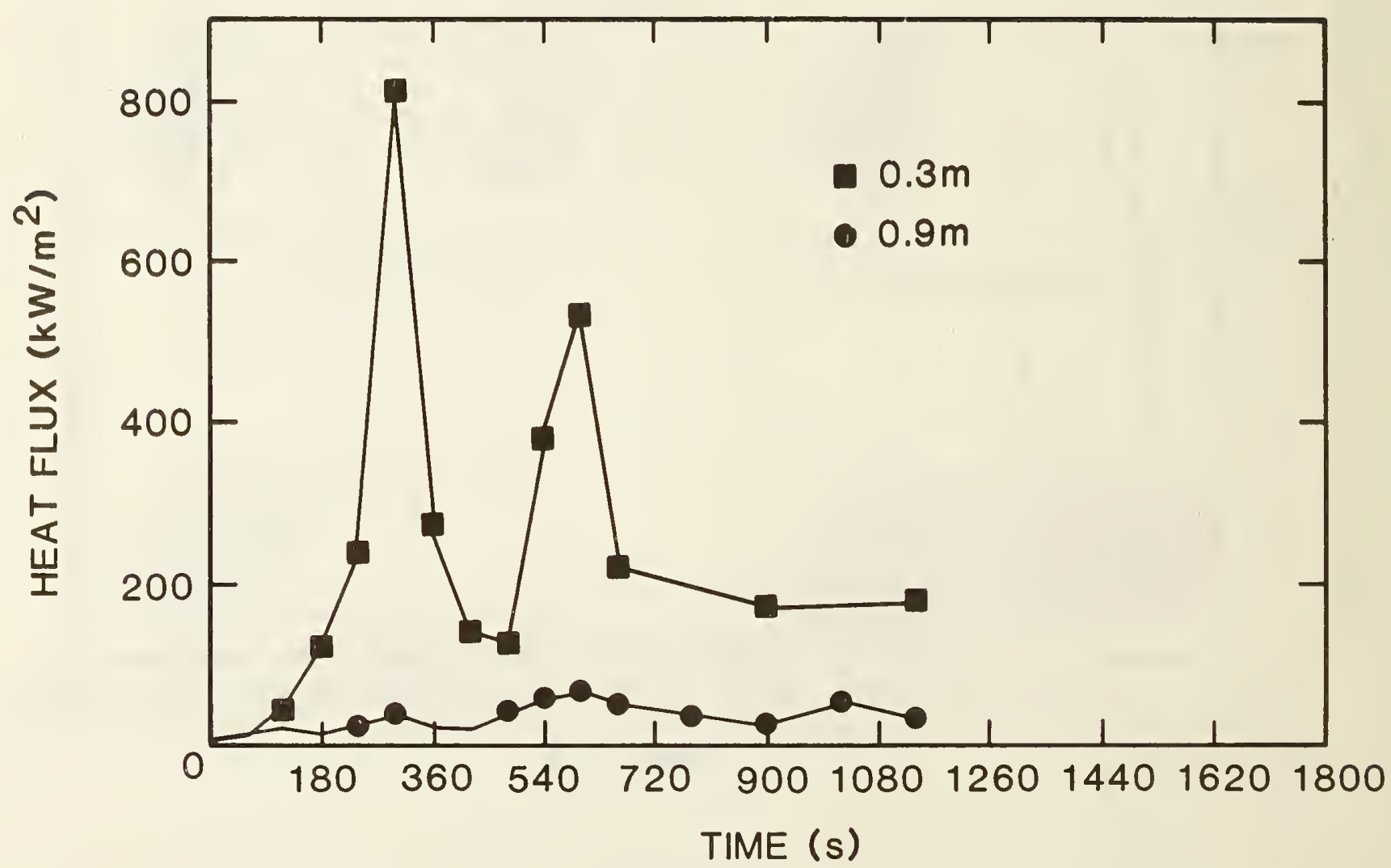

Figure 15. Incident Energy Profile Along Horizontal. Center Iine of Large Scale Fire Test Using Polycarbonate, $P C$, Glazing 


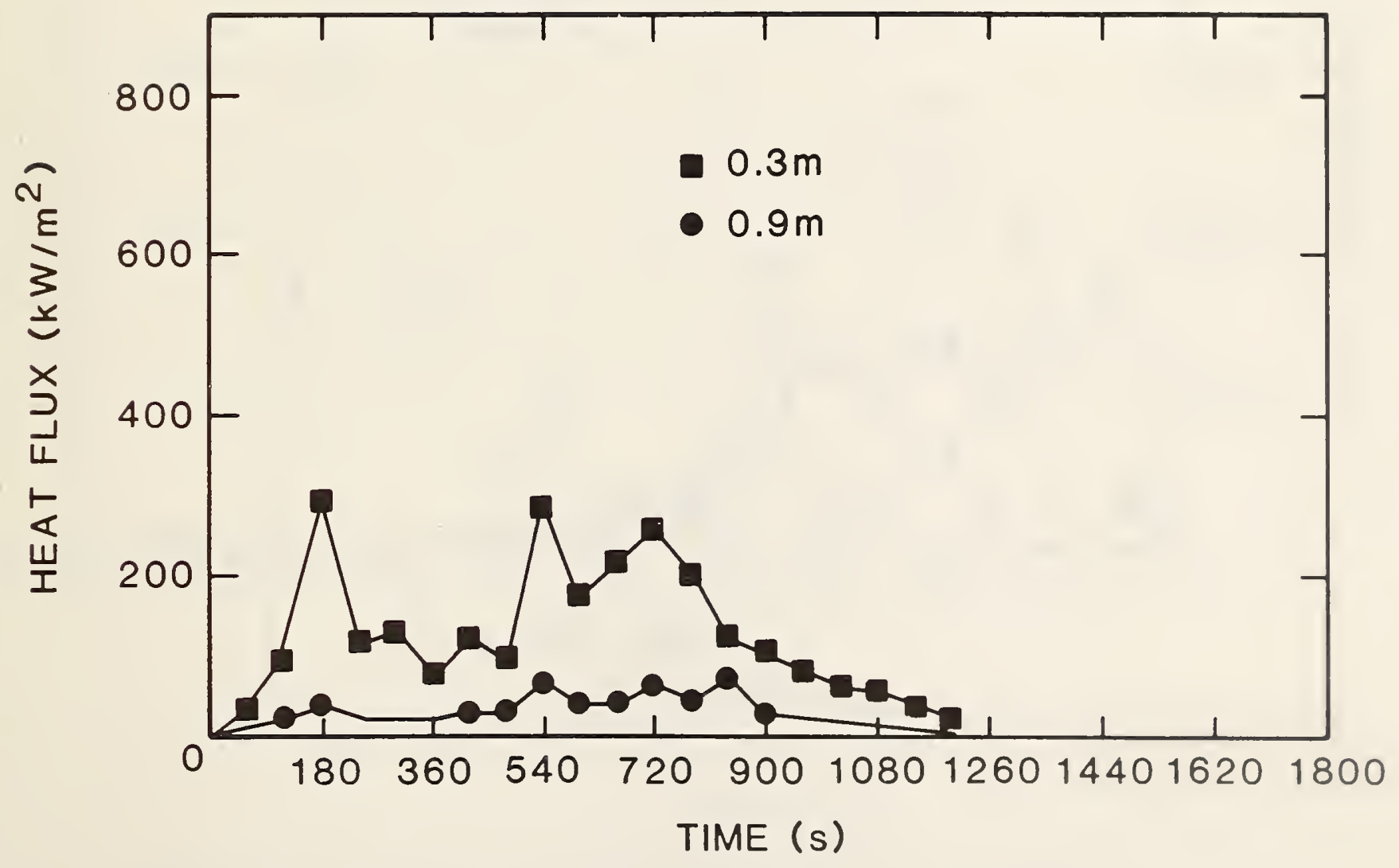

Figure 16. Incident Energy Profile Along Horlzontal Center Line of Large Scale Fire Test Using Glass Fiber Reinforced Plastic, FRP-2, Glazing 


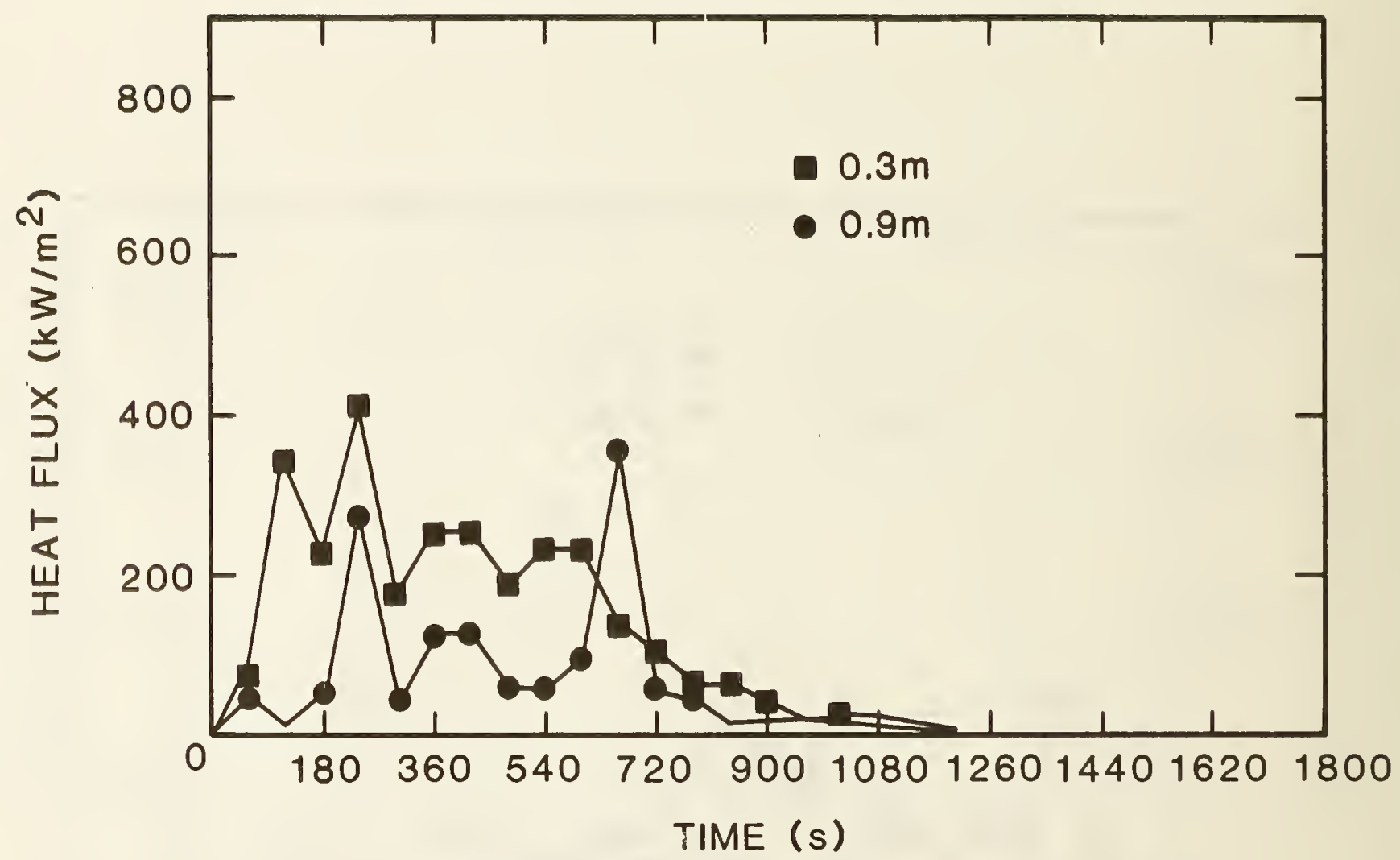

Figure 17. Incident Energy Profile Alnng Horizontal Center Line of Large Scale Fire Test Using Glass Fiber Reinforced Plastic, GRP-1, Glazing 


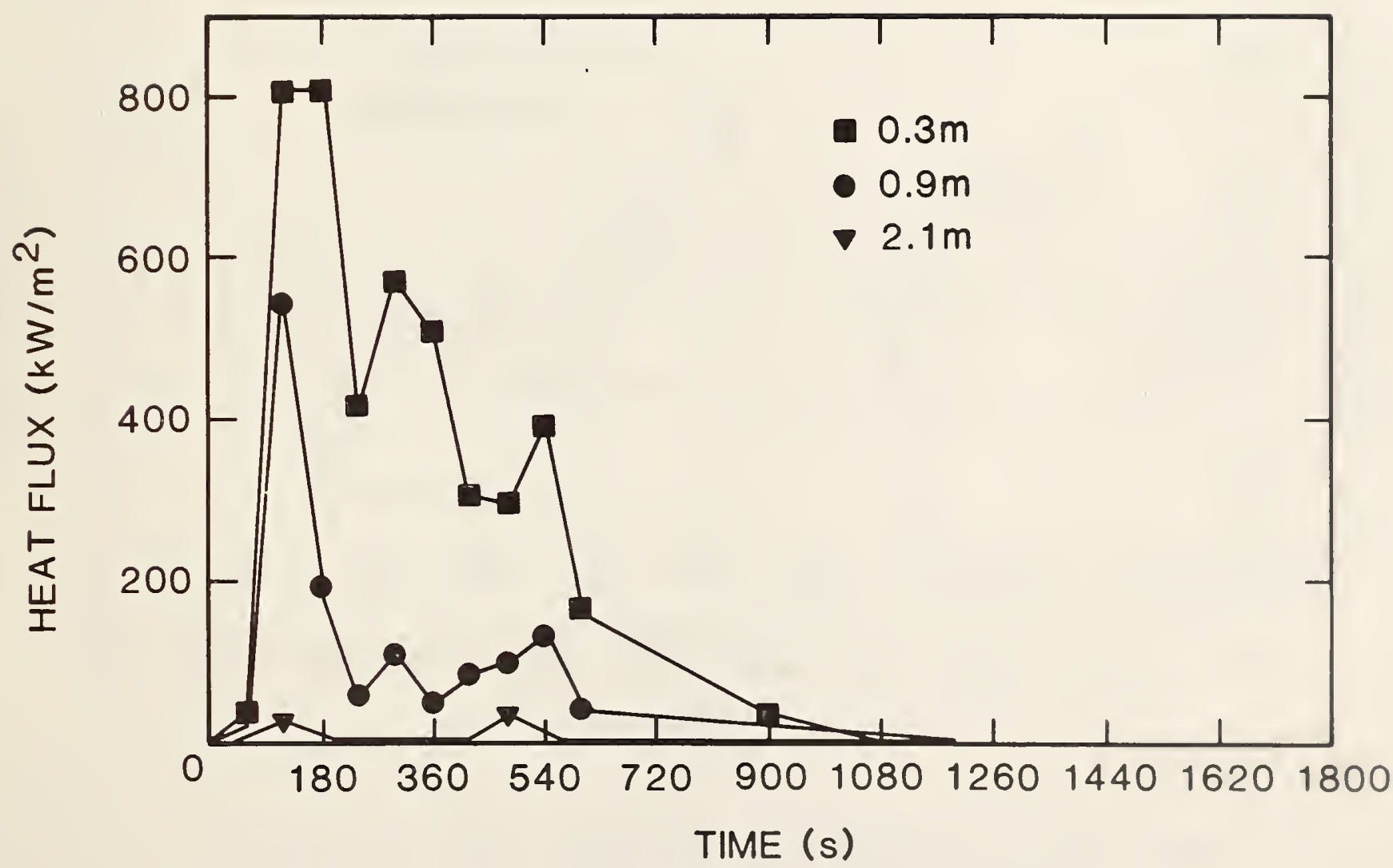

Figure 18. Incident Energy Profile Along Horizontal Center Line of Large Scale Fire Test Using PMMA Glazing 


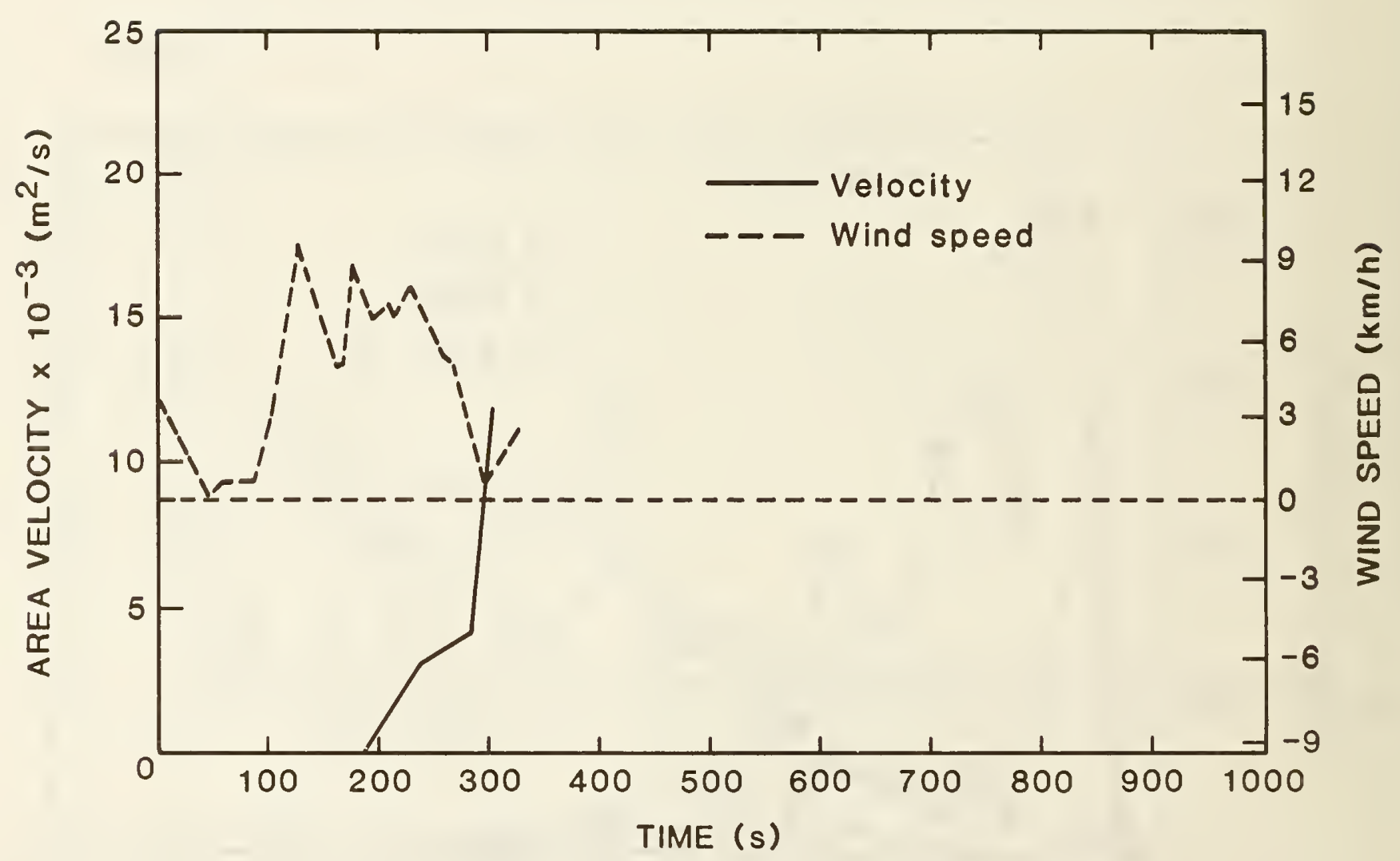

Figure 19. Flame Spread Rate and Wind Speed for Large Scale Fire Test Using Polycarbonate, PC, Glazing 


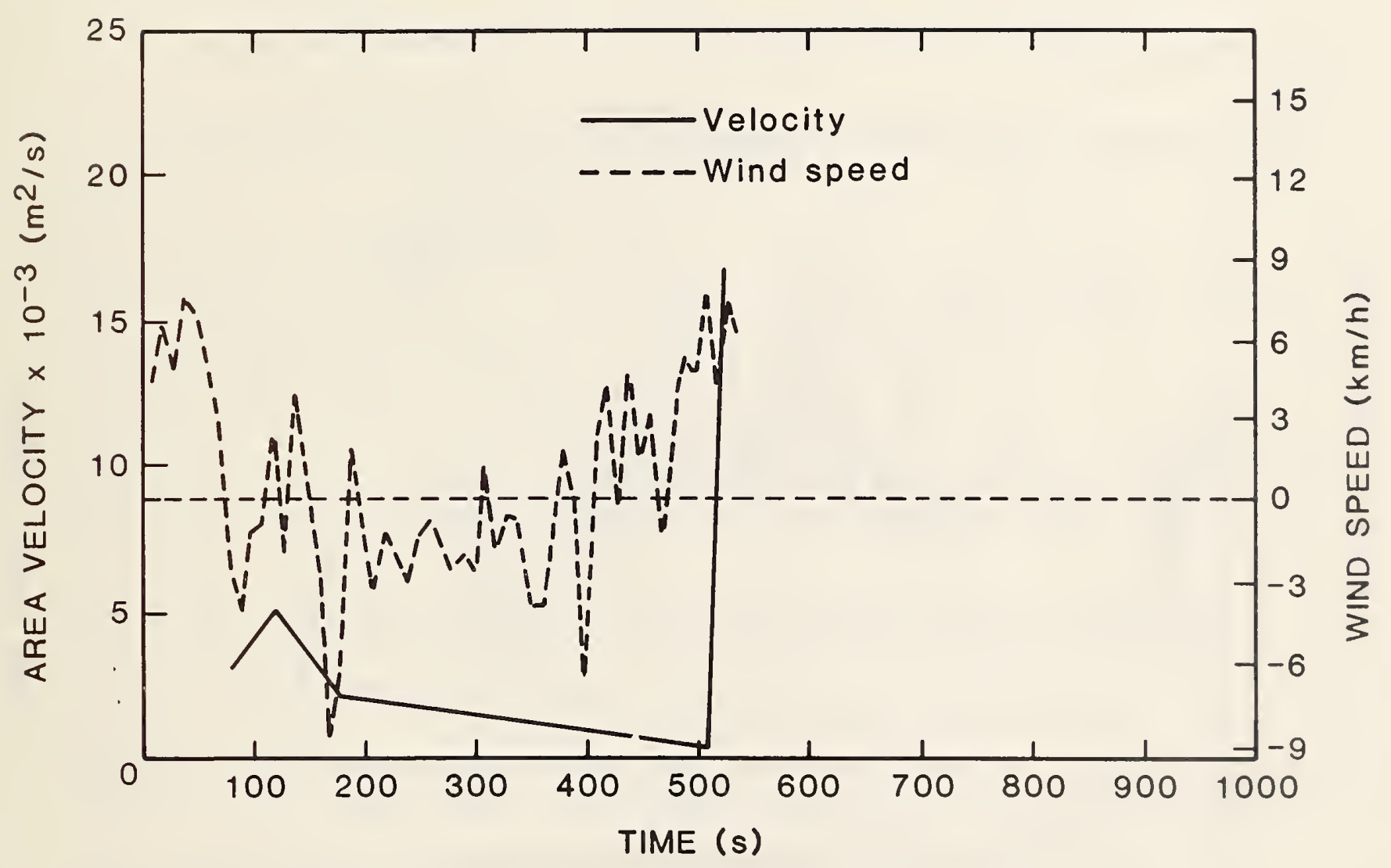

Figure 20. Flame Spread Rate and Wind Speed for Large Scale Fire Test Using GRP-2 Glazing 


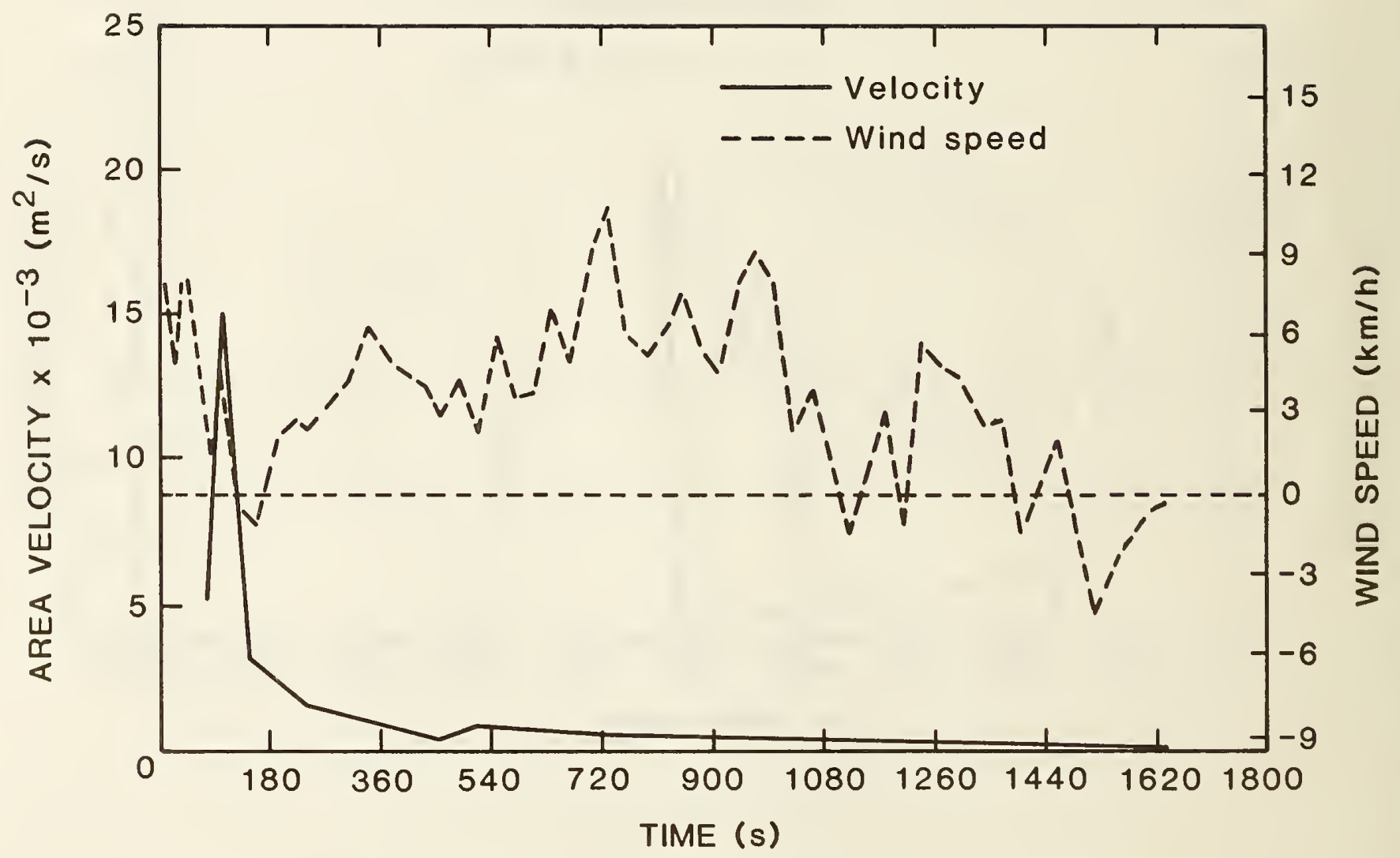

Figure 21. Flame Spread Rate and Wind Speed for Large Scale Fire Test Using GRP-1 Gl.azing 


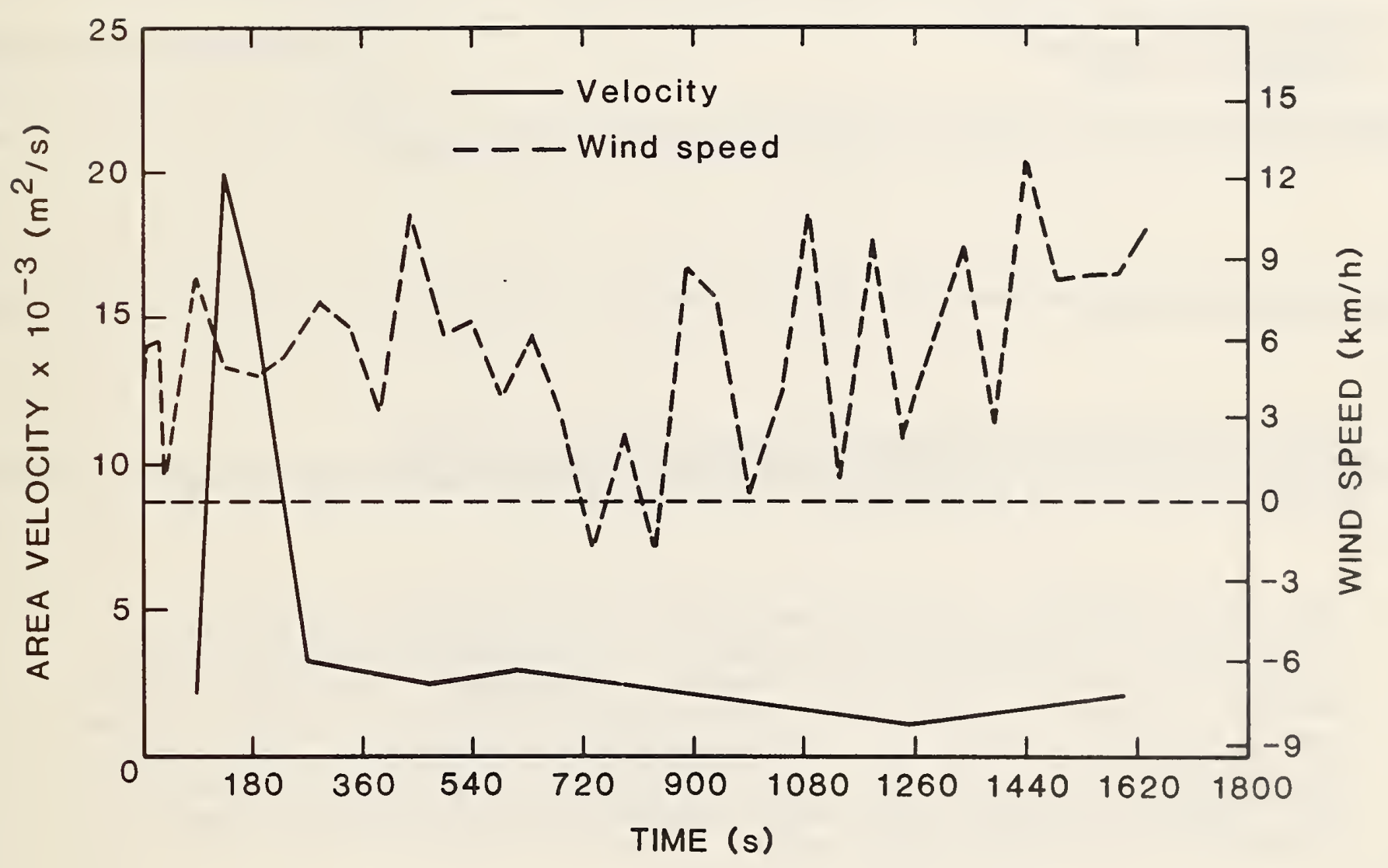

Figure 22. Flame Spread Rate and Wind Speed for Large Scale Fire Test Ising PMMA Glazing 
NBSEI HAA (REV, E.86)

U. 3 , DEPF: OF EOMM

BIBLIOGRAPHIC DATA

SHEET (SEe in stFuEtIOAS)

1. PU⿴LIEATION OR
REPORT NO.
NBSIR 84=2887

3. Publeation Date

4. FITLE AND SUBTITLE

Flame Spread on Combustible Solar Collector Glazing Materials

5. AUTHOR(S)

Emil Braun and Paula J. Allen

6. PERFORMING ORGANIZATION (If jolnt or other than NBS, see Instructions)

NATIONAL BUREAU OF STANDARDS

DEPARTMENT OF COMMERCE

WASHINGTON, D.C. 20234

9. SPONSORING ORGANIZATION NAME AND COMPLETE ADDRESS (Street, CIty, Stote, ZIP)

7. Contract Grant No.

8. Type of Report \& Perlod Covered

10. SUPPLEMENTARY NOTES

Document descrlbes a computer program; SF-185. FIPS Software Summary, is attached.

11. ABSTRACT (A 200-word or less factual summary of most signifleant information. If document includes a signlflcant blbllography or literature survey, mention It here)

The use of ASTM D635 and associated criteria as an evaluation method for solar collector glazings was investigated. Four materials commonly used in solar collector applications were evaluated by ASTM D635. Four other test methods were used to characterize the glazing materials as to ignition, flame spread, and heat release rate. These results were compared to large scale fire tests of these materials. Based on the large scale tests, it was found that ASTM D635 produced test results that were not consistent with those obtained from the large scale tests.

Good agreement was found between the rank ordering of the large scale tests and heat release rate and ignition properties as measured in the cone calorimeter and modified ISO test.

12. KEY WORDS (SIx to twelve entrles; alphabetical order; capltallze only proper names; and separate key words by semlcolons) ASTM D635; fire test; flame spread; glazing materials; ignition; large scale fire tests; rate of heat release; small scale fire tests; solar collectors.

For Officlal Distribution. Do Not Release to NTIS

Order From Superintendent of Documents, U.S. Government PrIntIng Office, WashIngton, D.C. 20402.

14. NO. OF PRINTED PAGES

62

15. Price

$\$ 10.00$

X] Order From National Technical Information Service (NTIS), Springfleld, VA, 2216I 

